\title{
Articles
}

\section{Making Sense of Overbreadth}

\author{
Richard H. Fallon, Jr. $\uparrow$
}

\section{INTRODUCTION}

More than fifty years after its inception, ${ }^{1}$ First Amendment overbreadth doctrine remains little understood. Characterized by both the Supreme Court and scholarly commentators as "strong medicine"2 that courts ought to administer cautiously, overbreadth doctrine is frequently a far weaker potion than either its champions or its critics have appreciated. This is especially true when a lower federal court pronounces a state statute void for overbreadth. ${ }^{3}$ Because state courts and lower federal courts stand in a coordinate, rather than a hierar-

† Harry M. Cross Distinguished Visiting Professor, University of Washington School of Law; Professor of Law, Harvard Law School. I gratefully acknowledge the help of Saul Levmore, Scott Matheson, Dan Meltzer, and Steve Shiffrin, who offered penetrating comments on earlier drafts. I also owe debts of gratitude to Jack Chorowsky, Jennifer Collins, Sandy Feinland, and John Parry for valuable research assistance.

1. See Thornhill v. Alabama, 310 U.S. 88, 105 (1940).

2. See, e.g., Osborne v. Ohio, 110 S. Ct. 1691, 1703 (1990); Redish, The Warren Court, the Burger Court and the First Amendment Overbreadth Doctrine, 78 Nw. U.L. REv. 1031, 1040 (1984) (both quoting Broadrick v. Oklahoma, 413 U.S. 601, 613 (1973)).

3. Overbreadth doctrine manifestly is strong medicine in the important category of cases in which federal courts, especially the Supreme Court, hold federal statutes unconstitutionally overbroad. A Supreme Court holding that a federal statute is fatally overbroad precludes narrowing constructions by the lower federal courts. See, e.g., United States v. Petrillo, 332 U.S. 1, 6 (1947); Monaghan, Overbreadth, 1981 SuP. CT. REV. 1, 32 n.134. A state's highest court's determination that a state statute is unconstitutionally overbroad is likely to be similarly draconian in effect. See infra text accompanying note 209 . As discussed below, see infra notes 8-16, 147-91, 275-303 and accompanying text, it is largely cases in which federal courts hold state statutes to be overbroad, but cannot foreclose state courts from furnishing narrowing constructions and thereby authorizing the statutes enforcement, that raise questions about the strength of overbreadth medicine. These cases are the central concern of this study. 
chical, relationship, ${ }^{4}$ the binding effect of the federal judgment extends no further than the parties to the lawsuit. ${ }^{5}$ Against nonparties, the state remains free to lodge criminal prosecutions. ${ }^{6}$ Civil actions can also go forward. The familiar vocabulary of "voidness," "invalidation," and "striking down" thus does more to mislead than describe.?

Even a Supreme Court determination that a state statute is void for overbreadth lacks the strong medicinal effects often ascribed to such a pronouncement. The Supreme Court has no authority to excise a law from a state's statute books. ${ }^{8}$ Nor can the Supreme Court bar a state court from providing a narrowing construction of an "invalidated" statute to ensure that it operates within constitutional bounds. What an "invalidated" statute means is a state law question; ${ }^{9}$ and whether the state court can and should change its interpretation in light of a Supreme Court overbreadth holding is also a state law question. ${ }^{10}$ All that the Supreme Court says when it holds a state statute overbroad, and all that it could say, is that the statute as authoritatively construed by the state courts prior to the Supreme Court's judgment is too sweeping to be enforced through the imposition of civil or criminal penalties. Following the Court's decision, it remains within the discretion of state authorities to seek limiting

4. See Shapiro, State Courts and Federal Declaratory Judgments, 74 Nw. U.L. REv. 759, 771 (1979).

5. The doctrine of federal supremacy does not bind a state court to accept a lower federal court's determination that a statute is unconstitutionally overbroad. Id. As a result, the only potentially binding doctrines are those of claim and issue preclusion, involving the constitutional faith and credit to which a federal judgment is entitled. Although questions concerning the force and applicability of these doctrines are governed by federal law, see, e.g., Degnan, Federalized Res Judicata, 85 YALE L.J. 741 (1976); Shapiro, supra note 4, at 763, claim preclusion generally does not extend to nonparties, nor should it so extend in cases in which a federal court holds a state statute to be unconstitutionally overbroad. See id. at 760-66. Determinations of overbreadth are intimately intertwined with state law questions of a statute's meaning and severability. This being so, state courts should not easily or routinely be precluded from pronouncing on the meaning and constitutionality of state statutes that might appear on their face to be overbroad, as would happen too often if the issue preclusive effects of a federal judgment of overbreadth were extended to nonparties to the original action. See id.; Note, The Res Judicata Effect of Declaratory Relief in the Federal Courts, 46 S. CAL. L. REV. 803, 850-51 (1973).

6. See, e.g., Doran v. Salem Inn, Inc., 422 U.S. 922, 931 (1975) ("[N]either declaratory nor injunctive relief can directly interfere with enforcement of contested statutes or ordinances except with respect to the particular federal plaintiffs, and the State is free to prosecute others who may violate the statute."); State v. Norflett, 67 N.J. 268, 285-87, 337 A.2d 609, 618-19 (1975); State v. McCluney, 11 N.C. App. 11, 13-15, 180 S.E.2d 419, 421 (N.C. Ct. App. 1971); Olvera v. State, 725 S.W.2d 400, 404 (Tex. Ct. App. 1987).

7. The consequences of a judicial holding that a statute is unconstitutional or void vary enormously across legal contexts. See Note, The Effect of Declaring a Statute Unconstitutional, 29 CoLuM. L. REv. 1140 (1929). The commonly credited notion that "[w] hen a statute is adjudged to be unconstitutional, it is as if it had never been," T. COOLEY, TREATISE ON THE CONSTITUTIONAL LIMTATIONS WHICH REST UPON THE LEGISLATIVE POWER OF THE STATES OF THE AMERICAN UNION 222 (6th ed. 1890), is sufficiently misleading to deserve condemnation as an "embarrassing popular metaphysical concept." Note, supra, at 1147; see also Nimmer, A Proposal for Judicial Validation of a Previously Unconstitutional Law: The Civil Rights Act of 1875, 65 COLUM. L. REV. 1394, 1413-21 (1965) (exploring theories and precedents suggesting that a statute held unconstitutional, even by Supreme Court, may subsequently be enforced).

8. See, e.g., Shapiro, supra note 4, at 767; Note, The First Amendment Overbreadth Doctrine, 83 HARv. L. REV. $844,892 \&$ n.180 (1970).

9. See, e.g., Gooding v. Wilson, 405 U.S. 518,520 (1972).

10. See, e.g., Time, Inc. v. Hill, 385 U.S. 374, 397 (1967); Dombrowski v. Pfister, 380 U.S. 479, 491-92 (1965). 
constructions of the affected statute in state court actions for declaratory judgments. ${ }^{11}$ When and if the state obtains an adequate narrowing construction, it can proceed to bring criminal prosecutions. ${ }^{12}$ In short, even a Supreme Court "invalidation" for overbreadth need not wholly nullify a state legislature's action in adopting a statute; in any case in which the state courts are able to supply narrowing constructions, the Court's decision at most imposes a hiatus, prior to the state's obtaining a constitutionally satisfactory interpretation, during which the statute cannot be enforced.

But what happens in the interim, notably to people who have been convicted for violations of a state statute that the Supreme Court has found to be overbroad? Must all who remain in prison-or at least all who are entitled to raise their claims under relevant non-First Amendment procedural doctrines ${ }^{13}$ - be released? At least one commentator has assumed so. ${ }^{14}$ Yet this assumption, which talk of "invalidation" and "strong medicine" encourages, is almost certainly mistaken. First Amendment overbreadth is largely a prophylactic doctrine, aimed at preventing a "chilling effect." 15 Insofar as only the doctrine's prophylactic aspects are involved, the remedial consequences of a Supreme Court judgment are largely matters for judicial policy choice. In most cases, it seems clear, a judgment that a statute is unconstitutionally overbroad creates no personal right to invalidation of convictions previously obtained. ${ }^{16}$

On the other hand, errors about the potency of overbreadth doctrine do not all lie in overestimates. The prophylactic concern with avoiding "chilling effect" drives an important element of First Amendment overbreadth doctrine, but does not constitute its whole. Portraying First Amendment overbreadth as irreducibly prophylactic, a plurality of the Supreme Court determined in the recent case of Massachusetts $v$. Oakes ${ }^{17}$ that a criminal defendant could not mount an overbreadth attack on the statute under which he was being prosecuted. Since the legislature had subsequently amended the statute to reduce its asserted overbreadth, the plurality reasoned, there was no more risk that it would "chill" constitutionally protected behavior, and thus no prophylactic justification for

11. See, e.g., Younger v. Harris, 401 U.S. 37, $50-51$ (1971); Dombrowski, 380 U.S. at 491-92 \& n.7.

12. See, e.g., Osborne v. Ohio, 110 S. Ct. 1691, 1699 (1990); Younger, 401 U.S. at 50-51; Dombrowski, 380 U.S. at $491-92$ \& n.7.

13. These include rules that preclude the raising of federal claims to challenge state convictions supported by an adequate state ground, such as a procedural default, see Meltzer, State Court Forfeitures of Federal Rights, 99 HARV. L. REV. 1128 (1986), and the various limitations on the availability of federal habeas corpus relief, see, e.g., Teague v. Lane, 489 U.S. 288 (1989) (barring review of most claims based on newly articulated rules of law); Stone v. Poweil, 428 U.S. 465 (1976) (barring litigation of most Fourth Amendment claims). For a general survey of federal habeas corpus relief and the limits on its availability in cases involving state criminal convictions, see P. BATOR, D. MELTZER, P. MISHKIN, \& D. SHAPIRO, HART \& WECHSLER'S THE FEDERAL COURTS AND THE FEDERAL SYSTEM 1465-578 (3d ed. 1988) [hereinafter HART \& WECHSLER].

14. See Bogen, First Amendment Ancillary Doctrines, 37 MD. L. REV. 679, 708 (1978).

15. See infra text accompanying notes 87-104, 114-24.

16. See infra text accompanying notes 159-65.

17. 109 S. Ct. 2633 (1989). 
permitting a challenge on grounds of overbreadth. ${ }^{18}$ But the plurality, although arguably correct in its assessment of the need for prophylaxis, erred in its legal analysis. Although the point is often lost sight of, First Amendment overbreadth doctrine has a constitutionally mandated core, involving the personal right of defendants not to be sanctioned except under a constitutionally valid rule of law, ${ }^{19}$ which appears to have been implicated on the facts of Oakes..$^{20}$ Once duly identified, the constitutionally required element of the doctrine ${ }^{21}$ gives rise to individual rights, and cannot be discarded for reasons of mere functional expediency.

The confusion engendered by overbreadth doctrine has yielded unfortunate effects. The idea that a federal court's overbreadth ruling irredeemably "voids" a state statute has occluded thought about a variety of issues, especially the implications of such a judgment for nonparties. Moreover, the assumption that overbreadth rulings are irreducibly draconian may have discouraged the Supreme Court from applying the doctrine consistently. ${ }^{22}$ Indeed, this particular misunderstanding could conceivably lead to the doctrine's abandonment. ${ }^{23}$ At the same time, failure to appreciate overbreadth doctrine's inner logic can lead to demonstrably incorrect results and the attendant violation of individual rights. Confusion occurs because of the doctrine's source. Although overbreadth doctrine rises to prominence in the heady garden of constitutional law, the roots that define its strength lie in the rocky and mysterious soil of federal courts doctrines. This is especially true in cases in which state statutes are challenged as overbroad in federal court-my exclusive concern in this analysis.

This Article has two aspirations. The first is descriptive and analytical: I hope to reduce First Amendment overbreadth doctrine to its component parts, show how they fit together, and dispel confusion over the implications of a judgment that a statute is void for overbreadth. My second aspiration is forward-looking and prescriptive: to develop a framework for thinking about the shape that overbreadth doctrine ought to take and, more specifically, to offer suggestions about when statutes should be held overbroad and what remedial consequences such holdings ought to have.

Because the doctrinal framework is multifaceted, the Article's analysis unfolds in stages. Part II develops some of the relevant background in federal courts law. It offers an account of the "ordinary" overbreadth doctrine that applies in cases outside the First Amendment, and of that doctrine's relationship

\footnotetext{
18. See id. at 2637-38 (O'Connor, J., plurality opinion).

19. See infra text accompanying notes $125-30$.

20. For a discussion of the case, see infra Section III.C.

21. For a fuller discussion of what it means to call overbreadth, or an element of it, "constitutionally required," see infra note 94.

22. Cf. Monaghan, supra note 3, at 24 (citing judicially developed "exceptions" to overbreadth doctrine as "evidence of the doctrinal disorder surrounding overbreadth analysis").

23. Cf. Osborne v. Ohio, $110 \mathrm{~S}$. Ct. 1691,1703 (1990) ("requiring that statutes be facially invalidated whenever overbreadth is perceived would very likely invite reconsideration . . . of the doctrine").
} 
to fundamental premises of the federal system. Part II also locates overbreadth doctrine in the context of substantive First Amendment law. Part III introduces two familiar theories of First Amendment overbreadth that often are viewed as opposed alternatives. One theory characterizes the doctrine as procedural or prophylactic, aimed at eliminating the "chill" that overbroad statutes cast on constitutionally protected speech. The other depicts First Amendment overbreadth doctrine as limited to vindicating the personal constitutional rights of the parties to a lawsuit. In roughest outline, Part III argues that these two conceptions of the doctrine should be viewed as complements, not rivals. The personal rights component of overbreadth doctrine is constitutionally mandated and irreducible, but narrow in scope. The prophylactic component, which is more amenable to judicial tailoring, both does and should function as an additional safeguard, and should be shaped to fit the need for prophylaxis in particular doctrinal contexts.

Part IV turns from theory to doctrine. More precisely, it employs the theories introduced in Part III to examine current doctrine and, in particular, to probe the question of just how "strong" overbreadth "medicine" really is. This analysis reveals that overbreadth determinations frequently have far less sweeping effects than the Supreme Court seems to assume. Part V identifies the conceptual building blocks with which courts might construct a more cost-effective overbreadth doctrine. Its generative assumption is that the prophylactic component of overbreadth doctrine permits judicial adjustment, not merely of the principles under which state statutes may be held overbroad, but of the effects of an overbreadth ruling. To return to issues that $I$ have noted already, whether an overbreadth determination by a lower federal court should bar enforcement of the affected statute in state court actions against nonparties and whether a Supreme Court invalidation mandates the vacation of all convictions previously obtained under the statute are largely questions for judicial policy choice.

With the structures for analysis thus developed, Part VI furnishes guidelines for identifying the types of statutes that courts should be most and least ready to hold overbroad. It then seeks to identify the optimal strength, in terms of remedial and preclusive effects, of overbreadth determinations by the Supreme Court and by lower federal courts. The aim, in other words, is to define the precise degree of potency that overbreadth medicine ought to have, and to identify the appropriate occasions for its administration. Finally, Part VII considers the linkage of overbreadth to the equally troublesome First Amendment vagueness doctrine. It argues that vagueness, in the First Amendment context, is best analyzed as a subcategory of overbreadth, and that overbreadth principles should govern vagueness issues. 


\section{OVERBREAdTH: THE GENERAL PROBLEM}

The basic overbreadth problem is easily framed: When should someone whose conduct is not constitutionally protected escape a legal sanction on the ground that the statute under which she is threatened would be constitutionally invalid as applied to someone else? ${ }^{24}$ An example is illustrative. In New York v. Ferber, ${ }^{25}$ the defendant was arrested and prosecuted for distributing two films "devoted almost exclusively to depicting young boys masturbating." 26 The Supreme Court had little difficulty concluding that Ferber's conduct, which was clearly prohibited by a New York criminal statute, merited no constitutional protection. ${ }^{27}$ But the statute, which forbade all traffic in depictions of children engaged in "sexual conduct," defined that term so broadly that it might reach some conduct that is constitutionally protected-selling medical textbooks or certain issues of National Geographic, for example. ${ }^{28}$ Thus Ferber's overbreadth argument: although his conduct was constitutionally prohibitable, the statute under which he was prosecuted was "overbroad" because it also prohibited constitutionally protected conduct that might be engaged in by others. In

24. See, e.g., Osborne, 110 S. Ct. at 1697 n.8; cf. L. TRIBE, AMERICAN CONSTITUTIONAL LAW \$ 12-27, at 1022 (2d ed. 1988) ("[O]verbreadth analysis ordinarily compares the statutory line defining burdened and unburdened conduct with the judicial line specifying activities protected and unprotected by the First Amendment; if the statutory line includes conduct which the judicial line protects, the statute is overbroad and becomes eligible for invalidation on that ground.").

25. 458 U.S. 747 (1982).

26. Id. at 752 .

27. Id. at 774 n.28.

28. Id. at 773. The Court did not explicitly hold such conduct to be constitutionally protected. It said that "whatever overbreadth may exist should be cured through case-by-case analysis of the fact situations to which its sanctions, assertedly, may not be applied." Id. at 773-74 (quoting Broadrick v. Oklahoma, 413 U.S. 601, 615-16 (1973)). Concurring in the judgment, Justices Brennan and Marshall expressed the view that such conduct would surely be protected. Id. at 775-77. Justice O'Connor, concurring separately, observed that she would find the question presented in such a case to be a hard one. According to her, the state's compelling interest in protecting minors against exploitation, which supported the Court's recognition in Ferber of a category of unprotected speech denominated as "child pornography," $i d$. at 774-75, "might in fact permit New York to ban knowing distribution of works depicting minors engaged in explicit sexual conduct, regardless of the social value of the depictions." Id. at 774 (O'Connor, J., concurring).

Whether the Court would hold works of acknowledged social value to be constitutionally unprotected, so long as they satisfied the judicially approved definition of "child pornography," is a question of general as well as specific interest. Leading First Amendment theorists, including Professors Ely and Tribe, have argued that a "balancing" methodology results in too little protection of speech, since a fact-specific analysis tends to magnify the harms of specific speech and to minimize the systemic interest in maintaining a system of free expression. See, e.g., J. ELY, DEMOCRACY AND DISTRUST 105-16 (1980); L. TRIBE, supra note 24, $\S 12-2$, at 789-94. These theorists prefer that the Court instead define protected and unprotected categories of speech, with speech in the unprotected categories being subject to prohibition on any rational basis and speech in the protected categories enjoying nearly absolute immunity. But the argument against balancing and in favor of a categorical approach clearly presupposes a small number of unprotected categories. If the number of unprotected categories expands-as it apparently did in Ferber through the recognition of a novel, unprotected "child pornography" category-balancing may look newly attractive as a means of protecting socially valuable speech at the fringes of what would otherwise be entirely unprotected categories. For a spirited defense of balancing by a First Amendment theorist who supports a highly speech-protective doctrine, see S. SHIFFRIN, THE FIRST AMENDMENT, DEMOCRACY, AND ROMANCE (1990). 
light of this overbreadth, Ferber argued, the Supreme Court should declare the statute unenforceable, with the consequence that he would go free.

To gain some perspective on this argument, it may help to examine the principles that govern "facial" challenges to statutes that would have some constitutionally impermissible applications in cases not involving the First Amendment or other rights protected by strict judicial scrutiny. ${ }^{29}$ I shall then turn to the First Amendment exception to ordinary overbreadth rules and discuss the relationship of overbreadth doctrine to substantive First Amendment principles.

\section{A. "Ordinary" Overbreadth and the Problem of Jus Tertii}

Outside the First Amendment context, the problem of when someone should be able to argue that a statute is "facially invalid," because it reaches constitutionally protected conduct that might be engaged in by parties not before the court, typically is treated as one of "third-party standing" or "jus tertii." 30 The general rule is clear: absent a relationship that makes the actual enjoyment of rights by a third party dependent on a challenger's capacity to assert those rights, ${ }^{31}$ one party may not escape the application of a statute on the ground

29. On the relationship between First Amendment overbreadth and least-restrictive-alternative analysis in cases involving other rights protected by strict or intermediate judicial scrutiny, see Monaghan, supra note 3, at 37-38. The question of whether a prophylactic overbreadth doctrine does or should extend beyond the First Amendment, to cases challenging statutes that allegedly infringe on other fundamental rights, has engendered a good deal of confusion. The Supreme Court stated recently that "we have not recognized an 'overbreadth' doctrine outside the limited context of the First Amendment." United States v. Salerno, 481 U.S. 739, 745 (1987); see also Schall v. Martin, 467 U.S. 253, 269 n.18 (1984) (outside First Amendment context, criminal statute cannot be attacked as overbroad). In all other contexts, the Court asserted, a challenger can successfully attack a statute on its face only if "there is no set of circumstances ... under which" the statute could constitutionally be applied. Salerno, 481 U.S. at 745 . But the doctrinal pattern is somewhat more complex. The Court, in the not-too-distant past, has rested squarely on overbreadth grounds in holding statutes that infringe too far on fundamental rights to be facially invalid. See, e.g., Planned Parenthood of Mo. v. Danforth, 428 U.S. 52, 81-84 (1976) (upholding facial challenge to state statute regulating abortion); Aptheker v. Secretary of State, 378 U.S. 500, 516 (1964) (finding overbreadth analysis proper where a statute encroaches on the right to travel, a "personal liberty protected by the Bill of Rights"). Moreover, despite the Court's recent assertions that overbreadth challenges are limited to the First Amendment area, virtually all of the abortion cases reaching the Supreme Court since Roe v. Wade, 410 U.S. 113 (1973), have involved facial attacks on state statutes, and the Court, whether accepting or rejecting the challenges on the merits, has typically accepted this framing of the question presented. See, e.g., Ohio v. Akron Center for Reproductive Health, 110 S. Ct. 2972 (1990); Hodgson v. Minnesota, 110 S. Ct. 2926 (1990); Webster v. Reproductive Health Servs., 109 S. Ct. 3040 (1989); Thornburgh v. American College of Obstetricians and Gynecologists, 476 U.S. 747 (1986). But see H.L. v. Matheson, 450 U.S. 398, $405-06$ (1981) (holding that challenger lacked standing to raise facial challenge to parental notification statute and upholding statute as applied).

30. For general discussions of third-party standing, see Monaghan, Third Party Standing, 84 CoLUM. L. REV. 277 (1984); Sedler, The Assertion of Constitutional Jus Tertii: A Substantive Approach, 70 CaLIF. L. REV. 1308 (1982); Note, Standing to Assert Constitutional Jus Tertii, 88 HARV. L. REV. 423 (1974).

31. See Note, supra note 30 , at 431 ("The link between the claimant's injury and the constitutional rights of third parties is the key element in identifying cases in which the assertion of jus tertii is necessary to preserve those rights."). 
that it would be unconstitutional as applied to someone else. ${ }^{32}$ In other words, overbreadth challenges are not allowed. ${ }^{33}$

Yazoo \& Mississippi Valley R.R. v. Jackson Vinegar $\mathrm{Co}^{34}$ is paradigmatic. Yazoo involved a state statute that required railroads to settle all claims for lost or damaged freight within a specified period of time. ${ }^{35}$ After the Yazoo Railroad failed to settle a claim by the Jackson Vinegar Co., the state court awarded actual damages and assessed a penalty under the statute for the railroad's failure to settle the case..$^{36}$ In the Supreme Court, the railroad argued that the statute was unconstitutional since, as written, it required the settlement of even extravagant claims. ${ }^{37}$ The Court, however, refused to look beyond the facts of the case before it, which involved a valid and reasonable demand for compensation. As viewed by the Supreme Court, the Yazoo Railroad, under the circumstances, was in effect attempting to assert the rights of a third party-some other railroad, perhaps, in a future case involving a false or frivolous claim. The Court refused to entertain the overbreadth argument that the statute would be unconstitutional as applied to another set of facts possibly involving another defendant. "This court must deal with the case in hand and not with imaginary ones," the Justices reasoned. ${ }^{38}$ "It suffices, therefore, to hold that, as applied to cases like the present, the statute is valid." 39

The Yazoo rule is harsh and in some ways counterintuitive. The challenged statute imposed pressure on railroads to settle even frivolous cases. The Court, in prescribing the approach that it did, bypassed a clear opportunity to consider

32. See, e.g., Osborne v. Ohio, 110 S. Ct. 1691, 1697 n.8 (1990); New York v. Ferber, 458 U.S. 747, 767 (1982); United States v. Raines, 362 U.S. 17, 20-26 (1960). Professors Monaghan and Sedler would formulate the rule somewhat differently: in their view, although parties should only be able to assert their own rights, one party's rights may, in the light of economic and other relationships, derive from the rights of others. See Monaghan, supra note 30, at 297-310; Sedler, supra note 30, at 1323-35. As a practical matter, in most cases the analysis changes little under this view. Generally, one party can claim rights arising by legal implication from the rights of others only when a relationship exists such that an injury to the challenger impinges on the others' constitutional rights. Most of the hard and interesting cases in which Monaghan's and Sedler's view might well have practical consequences-ones, for example, that would arise if Congress should ever try to abolish jus tertii standing by legislation-lie beyond the central concerns of this Article.

33. To put the point another way, under normal jus tertii principles, a litigant can generally invoke a third party's rights only when "a single application of a law both injures him and [thereby] impinges upon the constitutional rights" of one or more third persons. Note, supra note 30, at 424. In the First Amendment overbreadth context, by contrast, "[t]he overbreadth claimant seeks to assert the rights of hypothetical third persons," who she claims might independently be injured by a separate, actual, or threatened application of the law. Id. at 423-24. Although the rule against third-party standing may now be riddled with exceptions, see Monaghan, supra note 30 , at 288-89, none of the exceptions threatens the general principle that prohibits one party from asserting the rights of third parties with whom she stands in no special relationship and whose effective enjoyment of those rights would not be impaired by the statute's enforcement against the party in court.

34. 226 U.S. 217 (1912).

35. Id. at 218 .

36. Id. at 219 .

37. Id.

38. Id.

39. Id. at $219-20$. 
the permissibility of the statutory policy and, if it found injustice, to end it. Nonetheless, powerful reasons support the Yazoo rule.

First, when the defendant is guilty of conduct that can constitutionally be prohibited and that the state has endeavored to prohibit, the state should be able to inflict its punishment. ${ }^{40}$ Punishment infringes no personal right of the defendant. If a statute serves a valid purpose, a federal court should allow that purpose to be promoted insofar as the Constitution allows. Second, to permit litigation to turn on hypothetical applications of a statute would give too abstract a flavor to constitutional disputes. ${ }^{41}$ The judicial process works best when the issues are framed by concrete facts, which tend both to focus the dispute and to limit the scope of judicial decisionmaking. ${ }^{42}$

The third reason, which comes into play whenever a party asks a federal court to rule on the constitutionality of a state statute, involves concerns of federalism. A fundamental premise of constitutional federalism holds that state law is what the state courts say it is..$^{43}$ Thus, whether a state statute actually is overbroad, whether it means what it seems to say or something less than that, is a state law question on which state courts have the last word. ${ }^{44}$ Moreover, a related deep premise of constitutional federalism affirms that state courts not only can, ${ }^{45}$ but should, ${ }^{46}$ offer narrowing constructions of state statutes to confine their reach within constitutional bounds. This premise reflects a sort of federalistic quid pro quo. Asked of the states is a conscientious effort to shape their law to federal constitutional requirements. Accorded to the states is the flexibility to develop state law through a legislative/judicial partnership, in which the legislature can leave it to the state courts to dot its $i$ 's, cross its $t$ 's, and excise its constitutional excesses. ${ }^{47}$

The premises that underlie this third reason do not come without costs. They not only countenance but invite a "chilling effect" 48 whenever a statute ap(1986).

40. See, e.g., G. STONE, L. SEIDMAN, C. SUNSTEIN, \& M. TushNET, CONSTITUTIONAL LAW 1040

41. See, e.g., United States v. Raines, 362 U.S. 17, 22 (1960).

42. See id.; A. BICKel, THE LeAST DANGerous BRANCH 115-16 (2d ed. 1986).

43. See, e.g., Hart, The Supreme Court 1958 Term-Foreword: The Time Chart of the Justices, 73 HARV. L. REV. 84, 111 \& n.80 (1959); Meltzer, supra note 13, at 1133-34.

44. See, e.g., Gooding v. Wilson, 405 U.S. 518, $522-23$ (1972); Shapiro, supra note 4, at 766-67; Note, supra note 8 , at 894 .

45. See, e.g., New York v. Ferber, 458 U.S. 747, 768 (1982); Dombrowski v. Pfister, 380 U.S. 479, $491 \&$ nn.6 \& 7 (1965).

46. See, e.g., Fox v. Washington, 236 U.S. 273, 277 (1915) (Holmes, J.) ("it is to be presumed that state laws will be construed [to avoid infringement of constitutionally protected conduct] by the state courts").

47. See Hart, The Relations Between State and Federal Law, 54 CoLUM. L. REV. 489, 492-508 (1954) (emphasizing the lawmaking authority of the state courts); Dombrowski v. Pfister, 380 U.S. 479, 491 \& nn.6 \& 7 (1965) (recognizing the capacity of state courts to provide narrowing constructions of unconstitutionally overbroad state laws).

48. Although most often invoked in connection with First Amendment freedoms, the concept of a "chilling effect" logically embraces every situation in which people are deterred from engaging in conduct, especially constitutionally protected conduct, by fear of prosecution due to the costs or risks of defending a lawsuit. For a lucid explanation of the underlying assumptions of "chilling effect" arguments and of their 
pears to extend to constitutionally protected conduct. Able only to guess how a state court might respond, a citizen may hesitate before engaging in constitutionally privileged activity. Constitutional litigation is both hazardous ${ }^{49}$ and costly. ${ }^{50}$ But the premises hold and support the general rule: outside the First Amendment context, a challenger generally cannot attack a statute on the overbreadth ground that it would be unconstitutional as applied to someone else.

The due process clause or, more generally, the rule of law, requires two qualifications of the general rule. The first involves the technical doctrine of "separability." 51 When the Supreme Court, in a case such as Yazoo, upholds the constitutionality of a statute as applied, it necessarily assumes that any constitutionally invalid portions can be severed from the valid ones as a matter of state law. ${ }^{52}$ The Court assumes, in other words, that the state legislature, to the extent that it meant to prohibit any constitutionally protected conduct at all, did not intend to enact an all-or-nothing package. ${ }^{53}$ If the legislature did intend an all-or-nothing package, and if some parts of the package were found unconstitutional, no constitutionally valid rule of law would remain under which a defendant might be sanctioned..$^{54}$

Second, the record and jury instructions must leave no serious doubt that a defendant who is subjected to sanctions under an overbroad but severable statute was in fact found to have engaged in constitutionally prohibitable conduct. ${ }^{55}$ Although a statute may be written to sweep in both the good and the bad without therefore being invalid, the same cannot be true with respect to judicial decisions imposing sanctions. To conclude otherwise would be to allow states to punish constitutionally protected conduct and, again, to deny due process and jeopardize the rule of law.

significance in shaping substantive First Amendment law as well as overbreadth doctrine, see Schauer, Fear, Risk and the First Amendment: Unraveling the "Chilling Effect," 58 B.U.L. REv. 685 (1978).

49. See id. at 694-701.

50. See, e.g., Dombrowski, 380 U.S. at 486 ; Note, supra note 8 , at 855 \& nn.46-47.

51. For useful discussions of this familiar but little-analyzed legal concept, see Monaghan, supra note 3, at 4-23; Stern, Separability and Separability Clauses in the Supreme Court, 51 HARV. L. REV. 76 (1937).

52. See Monaghan, supra note 3, at 7-9.

53. The question of a statute's severability is a question of the state legislature's intent, see Monaghan, supra note 3, at 5-6, and, as such, is a state law question, see Note, supra note 8, at 894 .

54. See Monaghan, supra note 3, at 10 \& nn.35-36; Monaghan, Harmless Error and the Valid Rule Requirement, 1989 SUP. CT. REV. 195.

55. "[T] reasonable doubt of every fact necessary to constitute the crime with which he is charged." In Re Winship, 397 U.S. 358, 364 (1970). Under this standard, an inadequate jury charge can provide a ground for reversal, since it deprives the accused of a jury determination that she engaged in constitutionally prohibitable conduct that was made unlawful by statute. See, e.g., Osborne v. Ohio, 110 S. Ct. 1691, 1703-05 (1990); Ashton v. Kentucky, 384 U.S. 195, 198 (1966); cf. Pope v. Illinois, 481 U.S. 497, 503 (1987) ("harmless error" in charging jury concerning the constitutionally permissible elements of a crime is not a ground for reversal). 


\section{B. The First Amendment Exception}

Against the background of the ordinary rule that no one can challenge a statute on the ground that it would be unconstitutional as applied to someone else, a First Amendment exception has emerged. When speech or expressive activity forms a significant part of a law's target, the law is subject to facial challenge and invalidation if: (i) it is "substantially overbroad"-that is, if its illegitimate applications are too numerous "judged in relation to the statute's plainly legitimate sweep,"56 and (ii) no constitutionally adequate narrowing construction suggests itself. 57

\section{History}

Although the scope of First Amendment overbreadth doctrine has varied over time, a brief historical sketch should adequately frame current issues. Commentators trace the doctrine's origin to the 1940 decision in Thornhill $v$. Alabama ${ }^{58}$ in which the Supreme Court, departing from the traditional approach of determining whether a statute is unconstitutional as applied, deployed "[t] he newer and more aggressive method of reviewing overbroad laws on their face ... to determine whether a statute is too sweeping in coverage-and if so, invalid on its face." ${ }^{.59}$ Building on the tentative foundations left by its predecessors, a speech-protective Warren Court exhibited striking receptiveness to overbreadth challenges to statutes that impinged on speech and associational interests. ${ }^{60} \mathrm{It}$ did so despite occasional complaints that "invalidating" statutes, rather than merely adjudicating individual complaints that particular statutory applications violated constitutional rights, exceeded the proper bounds of the judicial function. ${ }^{61}$

More recently, the Burger and Rehnquist Courts have limited the doctrine in various ways, most importantly by adding the requirement that statutes must be substantially overbroad for the doctrine to apply. ${ }^{62}$ In addition, the Court

56. Osborne, 110 S. Ct. at 1697 (quoting Broadrick v. Oklahoma, 413 U.S. 601, 615 (1973)).

57. See, e.g., Erznoznik v. City of Jacksonville, 422 U.S. 205, 216 (1975); Dombrowski v. Pfister, 380 U.S. 479,491 (1965).

58. 310 U.S. 88 (1940). Professor Monaghan has termed Thornhill "the fountainhead of the overbreadth doctrine." Monaghan, supra note 3, at 11; see also Redish, supra note 2, at 1038-39 (asserting that practice of allowing facial challenges to overbroad statutes traces "as far back" as Thornhill).

59. Note, supra note 8 , at 845 (footnote omitted).

60. See Redish, supra note 2.

61. Cf. Younger v. Harris, 401 U.S. 37, 52 (1971) ("Procedures for testing the constitutionality of a statute 'on its face' ... are fundamentally at odds with the function of the federal courts in our constitutional plan.").

62. See, e.g., New York v. Ferber, 458 U.S. 747, $770-71$ (1982). Since the 1973 decision in Broadrick v. Oklahoma, 413 U.S. 601 (1973), the Court had explicitly applied a substantial overbreadth requirement to an ill-defined category of cases involving expressive activity that was not limited to "pure speech." Ferber extended the substantial overbreadth requirement to all First Amendment overbreadth cases. See Brockett v. Spokane Arcades, Inc., 472 U.S. 491 at 503 n.12 (1985). 
has held in at least one case that a facial attack on a statute may not be brought by a challenger who "desire[s] to engage in protected speech that the overbroad statute purports to punish." 63 When the challenger's own conduct is constitutionally privileged, the Court reasoned, a court should seize the opportunity to hold the challenged statute "invalid to the extent that it reaches too far," with the remainder "left intact." ${ }^{44}$ But the Court has not retreated from the proposition that there should be a First Amendment overbreadth doctrine, operating as an exception to the ordinary rule that statutes may not be challenged as facially overbroad.

\section{Overbreadth and Substantive Principles}

In order to play a useful role, First Amendment overbreadth doctrine must find its rationale in the substantive values underlying the First Amendment, and it must be sensibly integrated into substantive First Amendment principles. ${ }^{65}$ Although First Amendment doctrine is almost infinitely complex, ${ }^{66}$ two generalizations help to frame overbreadth issues. First, speech may be privileged under current doctrine either because it belongs to a constitutionally protected category, or because it merits protection as the result of a balancing test. ${ }^{67}$ Which type of privilege is relevant typically depends on the type of government regulation in question. If the government endeavors to regulate speech on the basis of content, the first and frequently dispositive question is whether the speech falls within a protected category. The Supreme Court has held some categories of speech—such as "obscenity" and "fighting words"--to be completely beyond First Amendment protection. ${ }^{68}$ The government may, if it so chooses, ban or regulate speech within these categories on the basis of its content.

63. Brockett, 472 U.S. at 504. Brockett seems to fit somewhat paradoxically with the Court's conclusion in Haig v. Agee, 453 U.S. 280, n.61 (1981), that overbreadth challenges may not be brought by litigants whose conduct falls within the "core" of a statute's valid sweep. The Court has also limited the doctrine's availability in cases involving commercial speech, see, e.g., San Francisco Arts \& Athletics, Inc. v. United States Olympic Committee, 483 U.S. 522, 536 n.15 (1987), and military regulations, see Parker v. Levy, 417 U.S. 733, 758-59 (1974).

64. Brockett, 472 U.S. at 504.

65. See, e.g., Bogen, supra note 14, at 681 (characterizing overbreadth as one of several "ancillary doctrines" that either "depend upon the basic First Amendment categorization and balancing analysis in their application" or that "help to ensure that the government was in fact focusing on its legitimate interests," as measured by substantive First Amendment standards, "when it took action affecting free speech"); $c f$. Monaghan, supra note 3, at 4-5, 24, 29-30 (arguing that defendant always has right not to be sanctioned except in accordance with constitutionally valid rule of law and that, if this principle has any special features in First Amendment context, those features must be entailed by substantive First Amendment principles).

66. The doctrine's overwhelming complexity is acknowledged both by those who try to understand it in terms of judicially created categories, see, e.g., Schauer, Codifying the First Amendment: New York v. Ferber, 1982 SuP. CT. REv. 285, and those who understand the doctrine at some level as irreducibly reflective of a balancing methodology, see, e.g., S. SHIFFRI, supra note 28 , at 9-45.

67. See L. TRIBE, supra note $24, \S 12-2$, at 789-94.

68. See, e.g., Miller v. California, 413 U.S. 15 (1973) (holding obscenity constitutionally unprotected); Chaplinsky v. New Hampshire, 315 U.S. 568 (1942) (holding "fighting words" constitutionally unprotected). 
By contrast, when speech enjoys full First Amendment protection, ${ }^{69}$ the state generally may not regulate it on the basis of content, even if the speech is harmful, unless the regulation is necessary to advance some compelling government interest. ${ }^{70}$ The "compelling state interest" test that is applied to content-based regulations of fully protected speech is a balancing test of a kind, but is generally not so labeled, due to the heavy presumption that regulation is impermissible. A different, more lenient test, commonly described as "balancing," "71 applies when government regulates on a content-neutral basis to promote interests that are unrelated to the message of regulated speech. ${ }^{72}$ For example, a prohibition against sound trucks in residential neighborhoods during the nighttime hours would be supported by interests unrelated to the message communicated and would therefore be tested under a much less stringent test than would a content-based regulation. ${ }^{73}$

This disparity in judicial treatment warrants the second pertinent generalization about substantive First Amendment principles: the relevant privilege rules treat regulations that are based on the content of speech as presumptively suspect, while manifesting a much greater tolerance for content-neutral regulations. $^{74}$

Against this background of substantive First Amendment privilege rules, at least four ways can be distinguished in which states may fail in their effort to design statutes that are not overbroad.

(i) The first involves efforts to regulate, burden, or prohibit speech or expressive activity, identified on the basis of content, in order to further some interest that the state believes to be compelling. For example, a variety of state and federal laws regulate contributions to, and expenditures by, organizations that seek to influence the outcome of political campaigns. ${ }^{75}$ Although political

69. At least since Chaplinsky most of First Amendment doctrine has developed under the assumptions of what is often called "the two-level theory of the First Amendment, according to which each category of speech is either protected or unprotected." L. TRIBE, supra note $24, \S 12-8$, at $833, \S 12-18$, at $928-29$, and the protected categories are not explicitly differentiated in terms of constitutional worth or value. Recently, however, the Court has recognized an intermediate, less than fully protected but not wholly unprotected, status. It has accorded this status to commercial speech, see, e.g., Central Hudson Gas \& Elec. Corp. v. Public Serv. Comm'n of N.Y., 447 U.S. 557 (1980), and labor speech, see, e.g., Getman, Labor Law and Free Speech: The Curious Policy of Limited Expression, 43 MD. L. REV. 4 (1984), and arguably to the categories of "sexually explicit" speech, see City of Renton v. Playtime Theatres, Inc., 475 U.S. 41, 49 \& n.2 (1986), and "private" speech as well, see W. LOCKHART, Y. KAMISAR, J. CHOPER, \& S. SHIFFIN, CONSTITUTIONAL LAW 791-803 (6th ed. 1986).

70. See, e.g., Boos v. Barry, 485 U.S. 312, 321, 334 (1988); First Nat'l Bank of Boston v. Bellotti, 435 U.S. 765, 786 (1978).

71. See, e.g., L. TRIBE, supra note $24, \S 12-2$, at 791-94.

72. See, e.g., Texas v. Johnson, 109 S. Ct. 2533, 2538 (1989).

73. Cf. Kovacs v. Cooper, 336 U.S. 77 (1949) (upholding prohibition against the use of loudspeakers in residential areas).

74. See, e.g., L. TRIBE, supra note 24 , § 12-2, at 789-94.

75. Both types of laws have attracted judicial challenge. See, e.g., Austin v. Michigan Chamber of Commerce, 110 S. Ct. 1391 (1990) (state regulation); Federal Election Comm'n v. Massachusetts Citizens for Life, Inc., 479 U.S. 238 (1986) (federal regulation). 
speech and organization lie at the heart of the First Amendment, ${ }^{76}$ the Supreme Court has held that the compelling government interest in averting corruption and its appearance can justify some limitations on contributions and expenditures. ${ }^{77}$ Obviously, however, laws of this kind could be written to reach more speech and expressive activity than the compelling interest in avoiding corruption would warrant. ${ }^{78}$

(ii) A second category of overbreadth encompasses statutes that purport to regulate a category of speech based on the belief that the category is constitutionally unprotected. In enacting statutes of this kind, government may err by defining the unprotected category more broadly than the Constitution permits. It might, for example, attempt to punish as unprotected "obscenity" speech that the Supreme Court would not allow to be so classified. ${ }^{79}$

(iii) A third category embraces statutes that aim to promote state interests unrelated to the content of speech or expressive activity and that infringe speech interests only incidentally. An example would be a state anti-trespass law. Most of the applications of such a law would not involve activities within the protections of the First Amendment. There could, however, be occasional applications to political or other expressive activities, some of which might reach further than the First Amendment allows. ${ }^{80}$

(iv) Finally, a fourth category of overbroad statutes aims to license or regulate speech in order to protect government interests-such as the interest in an orderly flow of traffic, or in maintaining quiet in residential neighborhoods during the nighttime- that are not related to the speech's content. Such purposes are not generally suspect. Yet if standards for the statutes' administration are not clearly specified, officials might apply them in such a way as to restrain too much speech or, worse, to disfavor speakers with whose messages they disagree. ${ }^{81}$ Statutes that fail to provide adequate safeguards against the administrative imposition of constitutionally impermissible restraints are therefore classifiable as overbroad. ${ }^{82}$

Although I have used and shall continue to use the "overbreadth" rubric generically, to refer to all of these four categories, distinguishing among them will sometimes facilitate clear thought about how the doctrine ought to be applied. Overbreadth has aptly been termed an "ancillary" doctrine, ${ }^{83}$ which

76. See, e.g., Austin v. Michigan Chamber of Commerce, 110 S. Ct. 1391, 1396 (1990).

77. See, e.g., id. at 1398 (upholding state law that prohibited corporations from making expenditures from their corporate treasuries in support of or in opposition to candidates for state office).

78. See, e.g., Buckley v. Valeo, 424 U.S. 1 (1976) (upholding some, but invalidating other, provisions of Federal Election Campaign Act of 1971 and its 1974 amendments).

79. See, e.g., Brockett v. Spokane Arcades, Inc., 472 U.S. 491 (1985).

80. See, e.g., Marsh v. Alabama, 326 U.S. 501 (1946).

81. See, e.g., City of Lakewood v. Plain Dealer Pub. Co., 486 U.S. 750, 757-69 (1988).

82. See, e.g., Broadrick v. Oklahoma, 413 U.S. 601, 613 (1973); J. NoWAK, R. ROTUNDA, \& J. YouNG, CONSTITUTIONAL LAW 840-41 (3d ed. 1986); Torke, The Future of First Amendment Overbreadth, 27 VAND. L. REV. 289, 295-99 (1974).

83. See Bogen, supra note 14. 
should be shaped to reflect the values and concerns that underlie substantive First Amendment principles. Although I shall say more about this issue later, an example may illustrate what I have in mind. Since substantive First Amendment doctrine exhibits special sensitivity to content-based regulations of protected speech, ${ }^{84}$ overbreadth doctrine should do so also. This helps to explain why the Supreme Court often does, and should, treat standardless licensing schemes as overbroad statutes subject to facial invalidation. ${ }^{85}$ Because such schemes vest administrative officials with statutorily unbounded discretion to determine what speech to allow and disallow, they may both invite and conceal forbidden content-based discrimination. ${ }^{86}$ By way of contrast, a regulatory statute that affects expressive activity only incidentally -an anti-trespassing law, for example-seems less likely to reflect legislative tolerance or encouragement of discriminatory enforcement. Moreover, when considering whether to hold such a statute overbroad, a court needs to worry about whether a narrower statute would adequately serve the government's needs in cases in which the First Amendment is not even implicated.

\section{THEORIES OF FIRST AMENDMENT OVERBREADTH}

First Amendment overbreadth doctrine has been explained and justified by two different sorts of theories. The more familiar explains the doctrine as reflecting a departure from ordinary principles forbidding the assertion of third-party rights. The other, which is narrower, holds that the doctrine reflects, and should sweep no more broadly than, the personal right of defendants not to be sanctioned under a constitutionally overbroad rule of law. Though neither theory is adequate in itself, each has something to contribute to a full understanding of First Amendment overbreadth doctrine.

\section{A. Prophylactic or Procedural Theories}

The most common account of the First Amendment overbreadth doctrine justifies a departure from ordinary standing principles in procedural or prophylactic terms. ${ }^{87}$ According to this account, the First Amendment enjoys a special status in the constitutional scheme. ${ }^{88}$ Any substantial "chilling" of constitutionally protected expression is intolerable. Third-party rights are too important to

84. See supra text accompanying notes $75-78$.

85. See, e.g., Broadrick, 413 U.S. at $612-13$ (listing cases in which Court has allowed facial challenges on this basis).

86. See, e.g., City of Lakewood v. Plain Dealer Pub. Co., 486 U.S. 750, $757-69$ (1988); Note, The Void-for-Vagueness Doctrine in the Supreme Court, 109 U. PA. L. REv. 67, 80-85 (1960).

87. See, e.g., Massachusetts v. Oakes, 109 S. Ct. 2633, 2637-38 (1989) (O'Connor, J., plurality opinion); New York v. Ferber, 458 U.S. 747, 768-69 (1982).

88. See, e.g., Dombrowski v. Pfister, 380 U.S. 479, 486-87 (1965), quoted in Osborne v. Ohio, 110 S. Ct. 1691,1699 n.12 (1990). 
go unprotected, ${ }^{89}$ and there may often be no better challenger than the one before the court. "Facial" attacks on and invalidations of overbroad statutes are therefore permitted in this area of the law. ${ }^{90}$

If grounded or rationalized in this way, First Amendment overbreadth doctrine constitutes an essentially procedural dispensation from the rules that otherwise disfavor both facial challenges to statutes and challenges that assert third-party rights. ${ }^{91}$ Either the doctrine does not describe any "personal" constitutional rights of the persons who are allowed to bring overbreadth challenges; $; 2$ or, if it does, the "rights" of the overbreadth challengers are recognized as "theirs" only as the outcome of a calculus that focuses in the first instance on the rights of others. Such a calculus would recognize rights in the overbreadth challengers merely as a means of ensuring against chill of the thirdparty rights that are of central constitutional concern..$^{93}$ In either case, the foundation for the doctrine is prophylactic: ${ }^{94}$ its purpose is to combat chilling effect and other impediments to constitutionally valuable expression..$^{95}$

89. See, e.g., Dombrowski, 380 U.S. at 486, quoted in Osborne, 110 S. Ct. at 1699 n.12.

90. See, e.g., Oakes, 109 S. Ct. at 2637-38; Ferber, 458 U.S. at 768-69.

91. See, e.g., Osborne, $110 \mathrm{~S}$. Ct. at $1697 \mathrm{n.8}$.

92. See, e.g., id. at 2637-38; Secretary of State of Maryland v. Joseph H. Munson Co., 467 U.S. 947, 958 (1984).

93. Note, supra note 8, conceptualizes overbreadth doctrine in substantially this way; $c f$. Monaghan, supra note 30 (conceptualizing third-party standing doctrine in this way and disapproving of cases upholding third-party standing that cannot be fitted into this mold); Sedler, supra note 30 (same).

94. By terming the doctrine "prophylactic," I mean to suggest two things. First, regardless of whether overbreadth challengers are regarded as rightholders, see supra notes 32-33 and accompanying text, the central constitutional concern is to protect-both from judicial sanction and from chill arising from the fear of being sued or prosecuted-the speech or expressive activity of persons other than those who are allowed to present overbreadth challenges. Second, I mean to imply that courts, and especially the Supreme Court, have discretion to adjust the doctrine's contours in light of their assessment of the doctrine's practical effects. Overbreadth doctrine rests on assumptions about uncertain and possibly shifting psychological and sociological variables such as the susceptibility of different forms of speech to deterrence by overbroad rules, the degree to which overbroad rules function as a cover for discriminatory law enforcement, and the utility of narrowly drawn statutes or limiting judicial constructions in averting chilling effects and in restraining discriminatory behavior by police and prosecutors. For a further discussion of these variables, see infra Parts $V$ and VI. Practical effects being a central focus of concern, the Court should perhaps feel that it has greater flexibility to adjust overbreadth doctrine than to alter a doctrine that operates exclusively by giving direct protection to the speech or conduct with which it is centrally concerned.

In using the term "prophylactic" in this way, I do not mean to suggest that First Amendment overbreadth doctrine is ungrounded in the constitutional text, or even that the First Amendment does not mandate an overbreadth doctrine of some kind or shape to create "breathing space" for First Amendment rights. NAACP v. Button, 371 U.S. 415, 433 (1963). But I do think it implausible, or at least misleading, to claim that the Constitution requires exactly the overbreadth doctrine that we have now, or indeed an overbreadth doctrine defined by any specific set of doctrinal rules. As Daniel Meltzer has argued, the Constitution may require that there should be some rule or doctrine to protect constitutional values, even when it does not require any particular rule or doctrine. See Meltzer, Deterring Constitutional Violations by Law Enforcement Officials: Plaintiffs and Defendants as Private Attorneys General, 88 CoLUM. L. REV. 247, 293-95 (1988). I view the prophylactic aspect of First Amendment overbreadth doctrine as constitutionally required in the former sense, but not the latter. Even if I did not, I would regard "prophylactic" overbreadth doctrine as defensible as an example of "constitutional common law." See, e.g., Meltzer, supra, at 294-95; Monaghan, The Supreme Court, 1974 Term-Foreword: Constitutional Common Law, 89 HARV. L. REV. 1 (1975). For a further discussion of this and related issues, see infra note 96.

95. For a fuller discussion of the values underlying overbreadth doctrine and how the doctrine helps to protect them, see infra Section V.A. 
The constitutional legitimacy of prophylactic doctrines has occasionally been questioned, ${ }^{96}$ but not, I think, persuasively ${ }^{97}$ There is no constitutional barrier under Article III. A party who is charged with violating a statute or threatened with imminent prosecution has standing in the constitutional sense. ${ }^{98}$ Moreover, once the constitutional requisites of a justiciable case are established, tradition permits private attorneys general to assert rights necessary to the protection of constitutional norms. ${ }^{99}$ Exceptions have emerged to the prudential

96. See, e.g., Younger v. Harris, 401 U.S. 37, 51-52 (1971); Grano, Prophylactic Rules in Criminal Procedure: A Question of Article III Legitimacy, 80 Nw. U.L. REv. 100 (1985); Schrock \& Welsh, Reconsidering the Constitutional Common Law, 91 HARV. L. REV. 1117 (1978). The challenges raise such a tangle of issues that it is difficult to keep them all straight. As Professor Strauss has persuasively argued, the "prophylactic" category is hard to separate in a sharp way from the broad and familiar category of rules that are deliberately drawn in overinclusive terms in order to avoid the kinds of costs and errors that effectively burden constitutional rights and that would, to some extent, inevitably attend case-by-case litigation. See Strauss, The Ubiquity of Prophylactic Rules, 55 U. CHI. L. REV. 190 (1988). Doctrines of this kind are especially familiar in the First Amendment context. See, e.g., id. at 195-204; Schauer, supra note 48 (arguing that "chilling effect" is central First Amendment concept and that many substantive First Amendment doctrines are structured to "overprotect" in order to minimize risk that protected speech might be chilled by uncertainty or fear of litigation). Special procedural doctrines, many of which are surely prophylactic in Professor Strauss's sense, are also common in the First Amendment area. See, e.g., Bogen, supra note 14; Matheson, Procedure in Public Person Defamation Cases: The Impact of the First Amendment, 66 TEX. L. REv. 215 (1987); Monaghan, First Amendment "Due Process," 83 HaRV. L. REV. 518 (1970).

Professor Grano, in common with Professors Schrock and Welsh, seems mostly to object to the judicial imposition of rules of decision that are not constitutionally mandated. In Grano's formulation, a rule or doctrine counts as prophylactic only when it establishes prohibitions against governmental conduct that the Constitution does not itself require: "What distinguishes a prophylactic rule from a true constitutional rule is the possibility of violating the former without actually violating the Constitution." Grano, supra, at 105. When the Constitution does not require a rule, Grano argues, the courts generally lack the authority to craft one. In emphasizing the gap between a prophylactic rule and the Constitution itself, however, Grano's formula seems too narrow to account adequately for a situation in which the Constitution requires the existence of some rule as a device for protecting constitutional values, but does not uniquely require any particular rule. See supra note 94 . The line between constitutional interpretation and constitutional lawmaking becomes deeply elusive in situations such as this. See, e.g., Meltzer, supra note 94, at 293-95; Meltzer, supra note 13, at 1167-76. More fundamentally, a rule allowing the federal courts to craft common law only under a standard of constitutional necessity would be historically novel, see Field, Sources of Law: The Scope of Federal Common Law, 99 HARV. L. REV. 881, 945-46 (1986), and substantively unwise, since it would deprive the constitutional system of so much flexibility as to threaten its workability. It is therefore unsurprising to find almost no support for so stringent a rule. See id.

With these more global objections put aside, I take it that the most serious challenge is to the legitimacy of federal judicial doctrines authorizing the award of judicial remedies to persons who have either no claim or at most a tenuous claim to be the bearers of the rights that they seek standing to assert. The text addresses this challenge alone.

97. For a lucid and persuasive defense of federal judicial power to craft prophylactic remedies that go beyond vindication of personal rights of the individual parties in whose cases they are granted and that are designed more broadly to deter official violation of constitutional norms, see Meltzer, supra note 94 , at 278-95.

98. See HART \& WECHSLER, supra note 13, at 166; Monaghan, supra note 3, at 1 n.1. To satisfy the constitutional requirements of standing, a party need only show that she has suffered an injury in fact that is fairly traceable to the challenged conduct and that is likely to be redressed by a favorable judgment. See, e.g., Valley Forge Christian College v. Americans United for Separation of Church and State, Inc., 454 U.S. 464, 472 (1982).

99. See Meltzer, supra note 94 , at $300-01$. 
rule against the assertion of third-party rights. ${ }^{100}$ Nor do these cases stand alone. The Fourth Amendment exclusionary rule is similar in substance and effect. In challenging the introduction of evidence obtained through an unreasonable search or seizure, a defendant does not assert a personal right to the exclusion of probative evidence, ${ }^{101}$ but appeals to a judge-made doctrine developed to deter violations of others' constitutional rights. ${ }^{102}$ When prophylactic theories of First Amendment overbreadth are located against this backdrop, the issue is not whether prophylaxis is constitutionally permissible, but whether it is desirable, and, if so, what shape prophylactic rules ought to take and what implications they ought to have. ${ }^{103}$

A prophylactic theory of First Amendment overbreadth is obviously a two-edged sword. On one side, a prophylactic theory countenances potential expansions of the doctrine to promote First Amendment values. On the other, such a theory licenses, even if it does not prescribe, judge-made cutbacks. ${ }^{104}$ Especially because prophylactic theories of First Amendment overbreadth fail to give the doctrine a clearly identifiable and constitutionally inviolable core, one further feature of such theories deserves mention. By embracing a prophylactic theory of the permissible outer reaches of overbreadth doctrine, someone does not logically exclude the possibility that the doctrine might have a hard-edged constitutional core that can be identified and defended on some other, nonprophylactic basis. Alternative theories should therefore be considered, not just as rivals, but as potential complements to prophylactic accounts of First Amendment overbreadth doctrine.

100. See, e.g., Caplin \& Drysdale, Chartered v. United States, 109 S. Ct. 2646, 2651 n.3 (1989); Monaghan, supra note 30, at 288-89. These exceptions can be recharacterized as involving first-party rights that are derivative of third-party rights. See supra note 32 . But this can also be done in overbreadth cases. See supra note 93 and accompanying text.

101. See United States v. Leon, 468 U.S. 897, 906 (1984); Stone v. Powell, 428 U.S. 465 (1976); United States v. Calandra, 414 U.S. 338, 347-48 (1974).

102. See, e.g., Stone, 428 U.S. at 486 ; Calandra, 414 U.S. at 347-48. The exclusionary rule might appear distinguishable from overbreadth doctrine on the ground that the former deters violations of constitutional rights in situations where courts, in the absence of the prophylactic doctrine, would have no realistic opportunity to make sure that officials conform to the bounds of law before constitutional violations occur. In the context of First Amendment overbreadth doctrine, it might be argued, no violation can occur until a court pronounces judgment, and there is no need for a prophylactic remedy to operate against a court. But prophylactic doctrines, at least in one sense of the term, are commonly framed to allocate the risk of erroneous adjudication. See supra note 96 . Moreover, especially in overbreadth cases involving ordinances that impose license requirements for different sorts of First Amendment activities, administrative officials have enormous power to violate First Amendment rights prior to any authoritative adjudication. For a discussion of this type of overbreadth case, see supra notes 81-86 and accompanying text.

103. On the degree of judicial discretion in shaping prophylactic rules, see supra note 94.

104. Cf. Massachusetts v. Oakes, 109 S. Ct. 2633, 2637-38 (1989) (O'Connor, J., plurality opinion) (suggesting that doctrine need not be applied in cases in which policy justification is insufficient to warrant it); Osborne v. Ohio, 110 S. Ct. 1691, 1702-03 (1990) (suggesting that overly stringent construction of implications of overbreadth holding could trigger cutbacks in doctrine's substantive reach). 


\section{B. Rights-Based Theories}

In contrast with prophylactic theories, an alternative account seeks to ground First Amendment overbreadth doctrine in individual rights. Professor Monaghan, for example, argues that the core of First Amendment overbreadth lies not in standing to assert third-party rights, but in the right of litigants "to be judged in accordance with a constitutionally valid rule of law." 105 In this view, a determination that a statute is constitutionally overbroad is a judgment on the merits about the rights of a party before the court ${ }^{106}$ - a judgment that sanctions imposed in the past were not imposed pursuant to a constitutionally valid rule of law or that the state lacks a constitutionally valid rule of law under which sanctions could be imposed at the present time.

An apparent difficulty with Monaghan's theory arises from the settled premise, discussed above, ${ }^{107}$ that the Supreme Court will assume state statutes to be severable; it will assume, as in the Yazoo case, that if a statute should be held unconstitutional in part, or as applied to particular sets of facts, that the state's courts would find the invalid parts or applications to be severable from the valid ones. ${ }^{108}$ Yazoo presents an apparent difficulty for Monaghan since it suggests that, so long as a statute is severable, the parts that are left after the state court has severed the invalid ones will always qualify as "a constitutionally valid rule of law." In attempting to respond, Monaghan argues that the severability premise holds only when - as in Yazoo-a state statute has received no authoritative construction by the state courts; in such cases the Supreme Court will assume that the state courts, although they have not said so, have in fact "fixed the statute's boundary at or within a clearly ascertainable line separating legitimate from illegitimate exercises of state power."109 But Monaghan argues that a state court cannot take this course in First Amendment cases. According to him, a special, substantive First Amendment rule requires that state courts, when parties claim First Amendment rights, must specifically articulate the constitutionally valid rule of law under which a defendant is subjected to sanctions. ${ }^{110}$ As a result of this substantive requirement of the

105. Monaghan, supra note 3, at 3. Professor Tribe employs a similar formulation, see L. TRIBE, supra note $24, \S 12-27$, at 1023-24, as does Note, supra note 8, at 848 (As "a theoretical matter the claimant is asserting his own right not to be burdened by an unconstitutional rule of law, though naturally the claim is not one which depends on the privileged character of his own conduct."). The great merit of Monaghan's article lies in its effort to provide an account of what does and does not count as a "constitutionally valid rule of law." In the absence of such an account, the claim that overbreadth doctrine vindicates individual rights represents conclusory rhetoric, not an analytical principle.

106. Monaghan, supra note 3 , at 4.

107. See supra notes 51-54 and accompanying text.

108. Monaghan of course recognizes this, see Monaghan, supra note 3, at 7, and deals with the issue at length. For a critique of his discussion, see infra text accompanying notes 114-30.

109. Monaghan, supra note 3 , at 7 .

110. See id. at 29-30. Monaghan does not explicitly identify the basis for his conclusion that a special, substantive requirement of the First Amendment calls upon state courts to articulate the applicable rule of law with greater precision in First Amendment cases than in cases involving other constitutional provisions. 
First Amendment, Monaghan concludes, there is "little scope for application of the Yazoo separability 'presumption'" 111 in cases involving First Amendment issues.

With this argument in place, Monaghan claims to find in severability doctrine a source of comparative strength, not weakness. It is the proponents of prophylactic theories of First Amendment overbreadth, he argues, who have no convincing account of why overbreadth doctrine should displace the settled severability principle exemplified by Yazoo and, what is more, displace that principle's underlying foundation in constitutional federalism. ${ }^{12}$ His own more modest theory, Monaghan argues, makes better sense of the relationship of overbreadth doctrine to deep principles of the constitutional order. ${ }^{113}$

Although artfully constructed and forcefully presented, Monaghan's theory is unconvincing along several dimensions. Severability doctrine-far from strengthening his account-proves its undoing. In the first place, Monaghan's theory that First Amendment overbreadth is concerned solely with the vindication of litigants' substantive rights cannot account for what the courts do. This is perhaps clearest with respect to anticipatory challenges to state statutes, which parties commonly raise in suits for injunctions and declaratory judgments. ${ }^{114}$ Under Monaghan's account of severability doctrine, the assumption in anticipatory actions should be that a state court, in a proper case, will furnish a construction that confines the challenged statute to constitutional bounds. ${ }^{115}$ In his view, a challenger should not be able to prevail without making an affirmative showing that a state court construction would yield an unconstitutional rule of law that would be applied against her. Yet the pattern of judicial decisions extends further. Supreme Court cases-including some relatively recent ones-reflect a view of First Amendment overbreadth as a sword, not just a shield, that should be available to attack statutes that appear inimical to First Amendment liberties and that lack a relatively obvious limiting construction.

But the assumption that substantive First Amendment rights are especially important and therefore entitled to special, procedural protection is by no means anomalous. This is the underlying assumption of prophylactic theories of First Amendment overbreadth. See supra Section III.A. In an article not concerned with overbreadth, Monaghan himself has explicitly argued that the First Amendment imposes procedural requirements that other constitutional provisions do not. See Monaghan, supra note 96 (arguing that the First Amendment requires heightened "due process" in case in which speech interests are threatened).

111. Monaghan, supra note 3 , at 29.

112. See id. at 14-23.

113. See id. at 14-23, 33-36.

114. Monaghan's discussion of these cases is somewhat opaque. See id. at 35-36.

115. Monaghan argues that the First Amendment imposes an obligation on state courts to indicate the precise rule of law that they are invoking at the time that they apply a statute, see id. at 29 , and that this substantive requirement of the First Amendment "leaves little scope for application of the Yazoo separability 'presumption" in First Amendment cases in which defendants seek Supreme Court relief from an adverse state court judgment, id. (footnote omitted). He has no adequate account, however, of why, under his theory, the Yazoo presumption should not continue to apply in anticipatory suits seeking a declaratory judgment that a statute is overbroad. On the contrary, he argues that a statute should be tested for constitutional adequacy only at the time and in the terms in which a court applies it to a litigant. Id. 
In City of Lakewood v. Plain Dealer Publishing Co. ${ }^{116}$ for example, the Court held that a newspaper could bring a facial challenge against a law requiring permits for locating newspaper vending racks on public property, without first applying for a permit to see whether the relevant authorities would apply the law consistently with constitutional standards. The result is hard to square with Monaghan's view that, even for purposes of overbreadth doctrine, a "statute cannot be evaluated, ex ante, in a vacuum, as it sits on the statute books .... [The time] at which to determine whether any statute is facially defective is at the time and in the terms in which it is applied to a litigant."117

Monaghan also has a far more forgiving view of what should count as an adequate narrowing construction than does the Supreme Court. For Monaghan it suffices if, at the time a state court applies a statute to a litigant, the court furnishes a "contextually specific construction" in "a negative form, for example: 'Defendant's trespass conviction is affirmed because the First Amendment does not include a right to" "engage in the conduct in which the defendant engaged. ${ }^{118}$ By contrast, the Court takes a more forward-looking view, aimed at averting the deterrence of constitutionally privileged behavior by other parties. In Board of Airport Commissioners v. Jews for Jesus, ${ }^{119}$ for example, the Court invalidated a facially overbroad enactment before the state courts had ever applied it, because, in the Court's estimation, it would take an indefinite number of litigated cases to produce a clear and comprehensive interpretation bringing the law within constitutional bounds. In Jews for Jesus, as in numerous other overbreadth cases, ${ }^{120}$ more was involved than vindicating an individual right not to be subjected to judicial sanctions under a constitutionally invalid rule of law. Some form of prophylaxis-an aim to avert chilling effects, or to prod state legislatures to write narrower statutes where First Amendment liberties are at stake-was at work.

A further deficiency of Monaghan's theory lies in its inability to explain why, if the overbreadth doctrine's sole concern is with individual rights and not with prophylactic protection of First Amendment values, a version of the "Yazoo presumption" should not apply even in First Amendment cases. In cases in which state courts have failed to formulate a constitutionally valid rule of law when applying a statute to a defendant, it would seem perfectly proper under Monaghan's view for the Supreme Court to vacate and remand the case for the state court, now provided with a corrected understanding of what federal law requires, to try again to formulate a constitutionally adequate rule of law

116. 486 U.S. 750 (1988).

117. Monaghan, supra note 3 , at 28-29.

118. Id. at 29 n. 119 .

119. 482 U.S. 569, 575-76 (1987).

120. See, e.g., Secretary of State of Maryland v. Joseph H. Munson Co., 467 U.S. 947 (1984) (upholding third-party standing to challenge statute as facially overbroad). 
under which the defendant's conduct would be prohibited. Although the defendant has a right not to be sanctioned except under a constitutionally valid rule of law, Monaghan emphasizes that there is no bar to a court's supplying an "interpretive gloss" for the first time in the context of litigation. ${ }^{121}$ This being so, it is hard to see why a litigant has a constitutional right to have her case dismissed because the state court erred in its judgment about what the First Amendment allows, any more than there is a constitutional right to have a case dismissed due to an erroneous jury instruction. Indeed, the Court has recognized that no such right exists. In at least one celebrated First Amendment case, Time, Inc. v. Hill, ${ }^{122}$ the Court vacated a state court's judgment as founded on a constitutionally inadequate rule of law, but remanded for further action in which the state courts might apply a constitutionally sufficient rule. In short, if all that is involved is a right not to be sanctioned under an unconstitutional rule of law, Monaghan has no convincing explanation of why the Court, in overbreadth cases, typically declares statutes invalid and orders prosecutions dismissed. ${ }^{123}$ Once again, it seems clear, a form of prophylaxis is at work. As I shall explain below, ${ }^{124}$ the Court, by imposing a penalty on the state, is creating incentives for state courts and especially for state legislatures to show greater solicitude for constitutionally protected speech.

Although Monaghan's specific theory thus fails to hold up, he is on to something important. The surrounding elaboration is mistaken, but his central claim is almost self-evidently correct: a litigant has a constitutional right not to be judged except in accordance with a constitutionally valid rule of law; and this means that a litigant always has a right to "challenge ... the constitutional sufficiency of the rule actually applied to" her. ${ }^{125}$ Monaghan's error lies in overestimating what this foundational principle cashes out to mean. Examination of settled severability rules, as reflected in cases such as Yazoo, reveals that, at least in some cases, the rule applied need not even be specified to be judged constitutionally adequate; it suffices that any constitutionally impermissible parts or applications of a statute may be severed from the rest. Once this is acknowledged, the practical meaning of the dictum that a litigant always has a right to be judged under a constitutionally valid rule of law can be captured by what I earlier described as the "rule-of-law" or "due process" qualifications to ordinary, or non-First Amendment, overbreadth doctrine: first, a statute that proscribes any constitutionally protected conduct is unconstitutional in its

121. See Monaghan, supra note 3, at 3. For recent corroboration of this point, see Osborne v. Ohio, 110 S. Ct. 1691, 1699 (1990).

122. 385 U.S. 374 (1967).

123. By the same token, if the state court has failed to apply a constitutionally valid rule of law, then, on Monaghan's view, "harmless error" analysis should not apply. See Monaghan, supra note 54. But the Supreme Court, again reflecting a view of overbreadth doctrine that is incompatible with his, has held otherwise. See Pope v. Mllinois, 481 U.S. 497, $507-11$ (1987) (Stevens, J., dissenting).

124. See infra text accompanying notes $220-23,275-303$.

125. Monaghan, supra note 3 , at 3. 
totality unless severable; ${ }^{126}$ and second, as the Court recently emphasized in Osborne v. Ohio, ${ }^{127}$ when a defendant is punished under an overbroad statute, the proof and jury instructions must be adequate to establish that the defendant's actual conduct was constitutionally prohibitable, not constitutionally protected. ${ }^{128}$

But recognition of the rule-of-law component in First Amendment overbreadth doctrine is significant, at least in some cases. Although this is sometimes overlooked in the heat of judicial battle, ${ }^{129}$ First Amendment overbreadth doctrine does not consist wholly of judge-made rules of prophylaxis. The doctrine has a clearly delineated constitutional core. ${ }^{130}$

\section{The Significance of the Distinction}

The Supreme Court's recent, fractured decision in Massachusetts $v$. Oakes $^{131}$ not only illuminates the distinction between the prophylactic and rule-of-law aspects of overbreadth doctrine, but also illustrates some of the confusions that follow when courts lose sight of that distinction. In 1982, the Massachusetts legislature enacted a statute that made it unlawful to take photographs displaying specified anatomical parts of anyone under the age of eighteen. ${ }^{132}$ Authorities arrested and prosecuted Douglas Oakes under the statute for taking "sexually provocative" pictures of "his partially nude and physically mature 14-year-old stepdaughter." ${ }^{133}$ Upon review of Oakes's conviction, the Massachusetts Supreme Court invalidated the statute as substantially overbroad, reasoning that it would forbid parents from photographing a bare-bottomed one-year-old toddling on the beach. ${ }^{134}$ The Massachusetts legislature then responded by adding a "lascivious intent" requirement to the criminal prohibition. ${ }^{135}$ But the state attorney general continued to seek Supreme Court reversal of the state court's overbreadth holding.

126. See, e.g., Brockett v. Spokane Arcades, Inc., 472 U.S. 491, 506 (1985).

127. 110 S. Ct. 1691, 1703-04 (1990).

128. The statute must also be written so as to give fair notice of the conduct that it aims to forbid. This is unlikely to be a problem with most overbroad statutes, whose general vice is that they give notice of an intent to proscribe too much conduct, including some that is constitutionally protected. $C f$. L. TRIBE, supra note 24, § 12-31, at 1034 (although concept of "fair notice" is often invoked in discussions of First Amendment vagueness doctrine, real concern "is that the "notice' may be too effective"). For a discussion of the fair notice problem and its relation to First Amendment vagueness doctrine, see infra Part VIL.

129. See infra notes $131-41$ and accompanying text.

130. What I have identified here as the constitutional core of First Amendment overbreadth doctrine was recognized by the Supreme Court's recent decision in Osborne v. Ohio, 110 S. Ct. 1691, 1703-05 (1990), but classified as an entailment, not of the First Amendment, but of the due process clause. I doubt that more than semantics is at stake. The Court has previously treated rights of this kind as linked to First Amendment doctrine. See, e.g., Thornhill v. Alabama, 310 U.S. 88, 96-98 (1940).

131. 109 S. Ct. 2633 (1989).

132. Id. at 2635-36.

133. Id. at 2636.

134. Id. at 2626-37.

135. Id. at 2638. 
With the case in this posture, Justice O'Connor, in an opinion joined by three other Justices, ${ }^{136}$ would have held that overbreadth doctrine did not apply to statutes no longer in force. ${ }^{137}$ The purpose of overbreadth doctrine, according to Justice O'Connor, was to avert chill, ${ }^{138}$ its medicine was unnecessary where a statute had been repealed or amended and there was no longer a chill to be avoided. ${ }^{139}$ The problem with this analysis is that it fails to take account of overbreadth doctrine's rule-of-law component. In holding the statute overbroad, the Massachusetts Supreme Court may have found the statute's unconstitutional applications to be inseparable from its valid ones ${ }^{140}$ as a matter of state law..$^{141}$ If so, there was no constitutionally valid rule of law under which Oakes, and others who had been convicted under the statute, could have been punished. The overbreadth doctrine therefore remained applicable, and unavoidably so, at least to this extent. Through her preoccupation with the prophylactic aspect of overbreadth doctrine, Justice O'Connor lost sight of the doctrine's rule-of-law core.

Writing for four other Justices in Oakes, Justice Scalia concluded that overbreadth doctrine remained applicable, but apparently for a different reason. ${ }^{142}$ He thought that if the Court found the statute "overbroad and therefore invalid," 143 it lacked the authority to adjust the available remedies on a policy basis; an invalid statute could not support a conviction. ${ }^{144}$ But there is at least a potential fallacy here, invited by the casual linkage between "overbreadth" and "invalidity." 145 A federal court may hold a state statute "overbroad," but it cannot "invalidate" a state statute in the sense of rendering it irredeemably null and void. ${ }^{146}$ Beyond vindicating what I have called rule-of-law requirements, a federal court can only rule that a state statute, until properly limited by state courts, should be deemed unenforceable as a means of promoting federal constitutional values. But how far a statute should be deemed unenforceable is at least in part a question of judicial policy.

Thus, just as overbreadth doctrine is less flexible than Justice $O^{\prime}$ Connor and the three Justices who joined her opinion assumed, it is not necessarily as rigid

136. Chief Justice Rehnquist, Justice White, and Justice Kennedy joined the opinion.

137. Oakes, $109 \mathrm{~S}$. Ct. at 2637-38.

138. Id. at 2638 .

139. Id.

140. The majority gave no explanation of why it did not attempt to sever any overbroad portions of the statute, as the dissenting opinion urged that it should. See Commonwealth v. Oakes, 401 Mass. 602 , 611 n.4, 518 N.E.2d 836, 841 n.4 (1988), rev'd, 109 S. Ct. 2633 (1989). One possible explanation is that the majority thought the statute inseparable, or that it believed the statute so overbroad that it required a legislative, rather than a judicial, restructuring.

141. The question of a statute's severability is a state law question. See Note, supra note 8, at 894.

142. Oakes, 109 S. Ct. at 2639 . Justices Brennan, Marshall, Blackmun, and Stevens joined Justice Scalia on this point.

143. Id. at 2640 .

144. Id. at $2639-40$.

145. Cf. Note, supra note 7, at 1147 (demonstrating that consequences of holding statute invalid are highly variable across contexts and mocking view that statute held unconstitutional is thereby rendered null).

146. See supra text accompanying notes 3-12. 
as Justice Scalia and the four Justices who joined him on this point thought that it must be. Justice Scalia, no less than Justice O'Connor, appears to have missed the distinction between the prophylactic and rule-of-law dimensions of overbreadth, and, in doing so, seems to have assumed erroneously that the strictures attaching to the latter apply equally to the former. Because issues surrounding the strength of overbreadth remedies appear to be little understood, a brief, doctrinal analysis may help to clear away some confusions and to frame some policy questions for informed resolution.

\section{HOW STRONG IS OVERBREADTH MEDICINE?}

In charting the effect of federal judicial holdings that state statutes are unconstitutionally overbroad, two principal categories of cases need to be distinguished. The first involves Supreme Court decisions rendered on review of state court judgments enforcing a state statute. The second consists of "anticipatory" actions in the lower federal courts to enjoin the enforcement of state statutes or to declare such statutes void and unenforceable on grounds of overbreadth. Within both categories, it is important to bear in mind the distinction between the two possible foundations for an overbreadth holding that were discussed in Part III. When holding a statute unconstitutionally overbroad, a court may either be vindicating a personal right of the challenger, or it may be acting on a prophylactic theory.

\section{A. Overbreadth in the Supreme Court}

When the Supreme Court holds a state statute overbroad, it rules, in effect, that the statute cannot be enforced until the state's courts provide a narrowing construction. ${ }^{147}$ Suppose, then, that the Supreme Court holds a state criminal statute unconstitutionally overbroad, but that the state, through a series of declaratory judgment actions, obtains a satisfactory narrowing construction. Clearly the state can prosecute violations occurring after the narrowing construction was obtained. ${ }^{148}$ But what about violations occurring before the state court performed its surgery? Does the Supreme Court's overbreadth holding bar prosecutions for these offenses? In Dombrowski v. Pfister, the Court suggested that it does not-at least not directly: "Our cases indicate that once an acceptable limiting construction is obtained, it may be applied to conduct occurring prior to the construction ... provided such application affords fair warning to the defendants." 149

147. See, e.g., Osborne v. Ohio, 110 S. Ct. 1691, 1699-1702 (1990); Younger v. Harris, 401 U.S. 37 , 50-51 (1971); Dombrowski v. Pfister, 380 U.S. 479, $491-92$ \& n.7 (1965).

148. See, e.g., Osborne, 110 S. Ct. at 1699-1702; Younger, 401 U.S. at 50-51; Dombrowski, 380 U.S. at $491-92 \&$ n.7.

149. Dombrowski, 380 U.S. at 491 n.7, quoted in Osborne, 110 S. Ct. at 1699. 
This carefully hedged dictum reflects two determinations. First, a defendant generally has no rule-of-law objection to punishment under a statute that received its constitutional shape only through judicial reconstruction. ${ }^{150}$ The statute means what the state court says it does. And the meaning, once identified by the state court, can be imputed retroactively to the legislature, no matter how counterfactual the court's ascription of intended meaning may be. ${ }^{151}$

The second determination is harder both to specify and to rationalize. It needs to be teased out of the dictum that retroactive application of a reconstructed statute might fail to give "fair warning to the defendants." ${ }^{152}$ On its face, the "fair warning" argument is circular. If the legal rule clearly provided that states could subsequently punish conduct occurring prior to a saving construction, everyone would have notice of the state's intent and capacity (provided that it could get an adequate limiting construction) to bring subsequent prosecutions. ${ }^{153}$

In addition, to reason by analogy, the warning problem in this context does not seem markedly greater than in the ordinary context in which a state legislature enacts a statute that appears on its face to be unconstitutionally overbroad; a defendant violates the statute; a state court, in the context of a criminal prosecution, renders a saving construction; and the defendant, before the Supreme Court, can challenge the constitutionality of the statute only as construed by the state court. ${ }^{154}$ In this familiar type of case, the statute would have been unenforceable unless judicially confined to constitutional limits. But the judicial limiting, even when it comes for the first time in an enforcement proceeding, presents no problem of fair warning. The potential defendant has notice that state courts can and should try to give statutes a saving gloss and that, if they do, a defendant can subject only the statute as "glossed," not the statute as written, to constitutional test. ${ }^{155}$ If this is so, however, it is difficult to see why the "fair warning" problem is any more serious when the recon-

150. See, e.g., Osborne, $110 \mathrm{~S}$. Ct. at 1699 . There is, on the other hand, a rule-of-law right to fair warning of a statute's intent to prohibit particular conduct. In Rabe v. Washington, 405 U.S. 313 (1972), for example, the Court found that the defendant's conduct would not have fallen within a statute's prohibitory ambit but for an unexpected construction by the state supreme court that had the practical effect of broadening the statute. In these circumstances, the defendant had no constitutionally adequate warning that his actions were proscribed, and the conviction was accordingly reversed. The "fair warning" rationale generally does not apply, however, in situations in which a statute that clearly attempts to proscribe conduct appears to sweep more broadly than the Constitution permits, and the only constitutional question is whether state courts will furnish a constitutionally adequate narrowing construction. In such cases, the defendant has adequate notice of the state's intent to seek to impose punishment if permitted to do so. See, e.g., Osborne, 110 S. Ct. at 1699.

151. See Note, supra note 8, at 894 ("matters of state legislatures' intent are for state courts to decide").

152. Dombrowski, 380 U.S. at 491 n.7.

153. See Younger v. Harris, 401 U.S. 37, 50-51 (1971) (arguing that holding of overbreadth is insufficient to eliminate chill because state may obtain narrowing construction and then proceed to prosecute prior conduct); Samuels v. Mackell, 288 F. Supp. 348, 354-55 (upholding prosecution for conduct occurring prior to narrowing construction on grounds that such a construction was "expectable") (S.D.N.Y. 1968) (Friendly, J.), aff'd on other grounds, 401 U.S. 66 (1971).

154. See Monaghan, supra note 3, at 20-21 \& nn.85-86 (collecting cases of this type).

155. See Osborne v. Ohio, 110 S. Ct. 1691, 1699-1702 (1990). 
structed statute was once declared "overbroad" by the Supreme Court, but the defendant again has notice-as provided by the Supreme Court in Dombrowski ${ }^{156}$ - that the state court may try to fashion a limiting construction.

The best explanation is that what the Court called a fairness issue in Dombrowski in fact reflects prophylactic concerns. If the aim of overbreadth doctrine is to eliminate "chilling effect," then some degree of assured protectiveness must be given to the Supreme Court's "overbreadth" determinations. ${ }^{157}$ The Court, for prophylactic reasons, might want to say: "Until the state has given a constitutionally adequate narrowing construction, our judgment is one that we want everyone to be able to rely upon." But the Court has not said explicitly that its overbreadth determinations have this protective effect-either for citizens generally or even for the parties to the case before it. Moreover, if I am right that the argument for the Court's doing so is only prophylactic, then it does not "have to."158 In any event, until the Court makes a further pronouncement, this important question regarding the strength of overbreadth medicine will remain unanswered.

Another aspect of the strength-of-the-medicine question involves the effect of a Supreme Court "invalidation" for overbreadth on judgments, notably criminal convictions, previously obtained under a statute. When the Court holds a criminal statute overbroad, must the state release from custody all those who have been imprisoned for its violation? ${ }^{159}$ Once again, the necessary effect of a holding of overbreadth depends upon the basis for the holding. If a statute as construed by a state court is unconstitutionally overbroad, then every person convicted under that statute has an irreducible, personal, rule-of-law right to be free from punishment if (i) the statute is inseparable as a matter of state law, ${ }^{160}$ or (ii) there is a reasonable question, in light of the proof and jury instructions, whether the convicting court lawfully found the person in question to have engaged in constitutionally prohibitable conduct. ${ }^{161}$ Sometimes a defendant will be able to establish that one or both of these conditions are satisfied. In Massachusetts v. Oakes, ${ }^{162}$ for example, the state court may have found the state's criminal statute inseparable as well as overbroad. ${ }^{163}$ More commonly, however, a defendant will be unable to establish a personal,

156. 380 U.S. at 491-92.

157. Cf. Younger, 401 U.S. at 50-51 (1971) (arguing that holding of overbreadth would frequently fail to eliminate chill, due to possibility, contemplated by prior Court decisions, that state might obtain narrowing construction of overbroad statute and thereafter prosecute conduct that occurred prior, as well as subsequent, to narrowing construction).

158. On the scope of the Court's discretion, see supra note 94.

159. I leave to one side here various procedural and substantive limitations on the doctrines defining the availability of post-conviction remedies. See supra note 13 and accompanying text.

160. See, e.g., Brockett v. Spokane Arcades, Inc., 472 U.S. 491, 506-07 (1985).

161. See Osborne v. Ohio, 110 S. Ct. 1691 (1990).

162. 109 S. Ct. 2633 (1989).

163. See supra notes $140-41$ and accompanying text. 
rule-of-law right under either condition. When this situation obtains, the question is in large part prophylactic: is the "sanction" of lost convictions necessary or appropriate to induce state legislatures and state courts to accord adequate respect to constitutional norms regarding free speech? As a doctrinal matter, the Supreme Court, in Osborne v. Ohio, ${ }^{164}$ recently intimated a negative answer. ${ }^{165}$

\section{B. Overbreadth in the Lower Federal Courts}

The potency of an overbreadth holding by a lower federal court, in a suit for an injunction or declaratory judgment, proves surprisingly hard to measure. In appraising the issues, it helps to distinguish between parties and nonparties to the federal action.

\section{Nonparties}

As noted above, a federal court's determination that a state statute is unconstitutionally overbroad, obtained in a declaratory judgment or injunctive action by one party, will not preclude the state from prosecuting nonparties to the federal lawsuit. ${ }^{166}$ As a purely doctrinal matter, the result is an overbreadth doctrine of exceedingly narrow scope. To see just how narrow, imagine a variation on the facts of Massachusetts $v$. Oakes. ${ }^{167}$ Before his arrest for violating a state statute forbidding the photographing of certain nude body parts of anyone under the age of eighteen, assume that Douglas Oakes sought and won a federal declaratory judgment that the statute was unconstitutional because overbroad. Imagine further that Oakes had a brother Daniel who, upon learning of his brother's courtroom success, proceeded to violate the statute. Douglas's federal declaratory judgment that the statute is unconstitutionally overbroad would fail to protect his brother from prosecution. It would furnish only a precedent that the state court is not bound to follow. ${ }^{168}$

There are, to be sure, avenues that litigants might pursue to avoid this result. Daniel might seek a declaratory judgment or injunction of his own. But the abstention doctrine of Younger v. Harris, ${ }^{169}$ coupled with the strict standing requirements that the Supreme Court has enforced in such cases, ${ }^{170}$ renders

164. 110 S. Ct. 1691 (1990).

165. See id. at 1702-03.

166. See supra note 6 and accompanying text.

167. 109 S. Ct. 2633 (1989).

168. See, e.g., State v. Norflett, 67 N.J. 268, 286, 337 A.2d 609, 618 (1975); State v. McCluney, 11 N.C. App. 11, 14, 180 S.E.2d 419, 421 (1971); Olvera v. State, 725 S.W.2d 400, 404 (Tex. Ct. App. 1987).

169. 401 U.S. 37 (1971). On the reach of Younger abstention doctrine, see HART \& WECHSLER, supra note 13 , at $1383-1438$.

170. The pattern of strict construction of standing requirements begins in Younger itself. See 401 U.S. at 41-42. I have criticized the Court's construction of the standing requirement elsewhere. See Fallon, Of Justiciability, Remedies, and Public Law Litigation: Notes on the Jurisprudence of Lyons, 59 N.Y.U. L. 
the award of such relief far from routine. Alternatively, in order to protect not only his brother Daniel but other parties who might be similarly situated, Douglas might have styled his suit for anticipatory relief as a class action. If he were successful in doing so, all class members would be able to claim the benefits of the federal declaratory judgment-whatever these benefits might be ${ }^{171}$-in subsequent criminal prosecutions. ${ }^{172}$ But class certification is not always easy, ${ }^{173}$ nor, in light of the state's legitimate interests, should it be. ${ }^{174}$ Thus, in many cases the analysis must end where it begins. A lower federal court's declaration that a state statute is unenforceable because overbroad, however beneficial to the prevailing party, confers no protection on nonparties to the litigation.

\section{Prevailing Parties}

Exactly how much protection does a lower federal court's declaration that a statute is unconstitutionally overbroad afford to a prevailing party? Here, at least, is First Amendment overbreadth the strong medicine that it is assumed to be? Imagine, for example, that Douglas Oakes, in a variation of the hypothetical introduced above, had convinced a federal district court to declare the troublesome Massachusetts statute unconstitutionally overbroad, and that the state failed to appeal. Assume further that the state, through enforcement actions against others in state court, obtained a constitutionally adequate limiting construction. In due course, the state asked the appropriate federal court to reopen the matter and vacate its prior judgment, which the court properly did. ${ }^{175}$ Can the state now prosecute Oakes for violating the statute? It clearly can prosecute him for conduct after the federal judgment was vacated. The harder question, which goes to the strength of the overbreadth medicine, is whether Oakes can be prosecuted for conduct occurring during the period in which he was "protected" by the federal judgment.

The Supreme Court has failed to provide a definitive answer, and lower court decisions, mostly in the form of dicta, ${ }^{176}$ yield little help. At the Su-

REv. 1 (1984).

171. See infra Section IV.B.2.

172. Although it was once said to be the rule that "a judgment of a civil court is not binding upon a court in which a criminal case is being tried," 46 AM. JUR. 2d Judgments $\$ 620$ (1969), the Supreme Court appeared to reject this argument in Yates v. United States, 354 U.S. 298 (1954), and there are persuasive policy reasons against it. See Note, supra note 5, at 825-31.

173. For a discussion of the requirements, see 7A C. WRIGHT \& A. MILLER, FEDERAL PRACTICE AND PROCEDURE §§ 1759-71 (2d ed. 1986).

174. See Shapiro, supra note 4, at 777-79.

175. On the appropriateness of the court's taking this step and the procedural mechanisms for its doing so, see id. at 776 n.90.

176. See, e.g., State v. Gates, 118 Ariz. 357, 359-60, 576 P.2d 1357, 1359 (1978) (suggesting that prosecution would be possible); State v. McCluney, 11 N.C. App. 11, 15, 180 S.E.2d 419, $421-22$ (1971) (same). 
preme Court level, Dombrowski remains the most-cited authority. ${ }^{177}$ But its dictum, quoted above, is deliberately elusive. ${ }^{178}$ Chief Justice Rehnquist has expressed his view that a federal declaratory judgment has no conduct-privileging effect. ${ }^{179}$ In Edgar v. MITE Corp., ${ }^{180}$ a case viewed by four Justices as presenting an analogous but certainly distinguishable issue, ${ }^{181}$ Justices Brennan, Marshall, and Powell opined that a federal injunction and declaratory judgment that were vacated on appeal as erroneously granted would immunize conduct engaged in during their pendency. ${ }^{182}$ Justice Stevens, however, expressly disagreed. ${ }^{183}$

Beyond the Justices' individual pronouncements, two points seem clear. First, the rule-of-law aspect of overbreadth doctrine does not mandate a result here, any more than it does in other cases involving the Dombrowski dictum. ${ }^{184}$ So far as the rule of law is concerned, it suffices that the overbroad portions of the statute were found severable by the state courts and that the jury instructions and proof assure that the defendant's conduct was not in fact constitutionally protected.

Second, when the issue is seen to involve prophylactic overbreadth, there are forceful arguments on both sides. The argument against holding that a federal judgment confers immunizing effect begins with the principle that state statutes mean what the state courts say they mean. ${ }^{185}$ If a state court provides a constitutionally adequate narrowing construction, a statute is not overbroad. And if a statute is not overbroad or otherwise constitutionally invalid, a federal court lacks the constitutional warrant to preclude its enforcement. ${ }^{186}$ On the other side stand arguments rooted in the policies of the Declaratory Judgment $\mathrm{Act}^{187}$ and prophylactic overbreadth doctrine. Immunizing the conduct of prevailing parties may be necessary to constitute a declaratory judgment as the prompt, effective, and final remedy that its framers envisaged. ${ }^{188}$ The animating purposes of prophylactic overbreadth doctrine-especially the desire to avert chill—may also require recognizing the

177. See, e.g., Osborne v. Ohio, 110 S. Ct. 1691, 1699 (1990); Younger v. Harris, 401 U.S. 37, 50-51 (1971).

178. "[O]nce an acceptable limiting construction is obtained, it may be applied to conduct occurring prior to the construction ... provided such application affords fair warning to the defendants ...." Dombrowski, 380 U.S. 479, 491 n.7 (1965).

179. See Steffel v. Thompson, 415 U.S. $452,482-83$ (1974) (Rehnquist, J., concurring).

180. 457 U.S. 624 (1982).

181. For a further discussion of the issue in Edgar v. MITE, which involved the protective effect, if any, of a declaratory judgment or injunction that is vacated on appeal as erroneously granted, see infra note 191.

182. See MITE, 457 U.S. at 657 n.1, 658 (Marshall \& Brennan, JJ., dissenting); id. at 646 (Powell, J., concurring in part).

183. See id. at 647-54.

184. See supra notes $150-58$ and accompanying text.

185. See supra text accompanying notes $43-44$.

186. See MITE, 457 U.S. at 647-54 (Stevens, J., concurring).

187. Federal Declaratory Judgment Act of 1934, ch. 512, 28 U.S.C. $\$ \S 2201,2202$ (1988).

188. See S. REP. No. 1005, 73d Cong., 2d Sess. 2 (1934). 
protective effect of declaratory judgments, even after they are vacated. Finally, there is a remote Supreme Court precedent, ${ }^{189}$ not cited in any of the recent opinions, in which Justice Brandeis provided at least indirect support for the proposition that conduct occurring under protection of a federal judicial order remains privileged after the order is vacated. In finding a plaintiff entitled to a preliminary injunction against a state rate law, Brandeis held that if "upon final hearing the maximum rates fixed should be found not to be confiscatory, a permanent injunction should, nevertheless, issue to restrain enforcement of penalties accrued pendente lite . . . "190

With no definitive modern holding by the Supreme Court and with the contending arguments and authorities balanced in this way, a reasonably cautious lawyer could only pronounce the law unsettled. There is no sure answer to the question whether a declaratory judgment continues to immunize the conduct of a prevailing party after the judgment has been vacated in the wake of a state court's narrowing construction. ${ }^{191}$ Moreover, even if a declaratory judgment were held to confer a permanent immunity-and I emphasize again that there is no clear, authoritative holding to this effect-First Amendment overbreadth doctrine might still emerge as somewhat less potent a medicine than is often imagined. If the protection were based on the Declaratory Judgment Act, then the potency would not be that of overbreadth doctrine, but of the statute under which federal relief is sought. And if overbreadth doctrine itself establishes the protective power of the lower federal court's judgment, it is the contestable and alterable prophylactic aspect of the doctrine that does so. In short, even if overbreadth doctrine were strong medicine in this context-and, again, it is a big "if"- that medicine would consist more of judicial policy than of constitutional mandate, and would therefore be subject to policy-driven dilution.

Before any further advance can be made, it will be necessary to think carefully about the values that underlie prophylactic overbreadth doctrine, and about the costs that the doctrine entails.

189. Oklahoma Operating Co. v. Love, 252 U.S. 331 (1920).

190. Id. at 338.

191. The state of the law concerning the closely related question mooted in Edgar v. MTTE Corp., 457 U.S. 624 (1982)-involving the effect of a declaratory judgment or injunction that is vacated on appeal as erroneously granted-is similarly clouded. Despite the inconclusive discussion in MITE, it would seem arguable that Oklahoma Operating Co. v. Love, 252 U.S. 331 (1920), remains controlling authority in this context. On the other hand, Oklahoma Operating Co. can be read to rest on the proposition, which may no longer be tenable, that the due process clause requires a practically effective opportunity to test the constitutionality of a statute in an anticipatory suit for declaratory or injunctive relief. $C f$. Hart, The Power of Congress to Limit the Power of Federal Courts: An Exercise in Dialectic, 66 HARV. L. REv. 1362, 1366 (1953) ("Congress necessarily has a wide choice in the selection of remedies, and ... a complaint about action [withholding a particular remedy] can rarely be of constitutional dimension."). For a suggestive but inconclusive discussion about whether the Constitution may sometimes require the availability of an anticipatory action for declaratory or injunctive relief, see HART \& WECHSLER, supra note 13, at 379-80. 


\section{TOWARD A GENERAL FRAMEWORK}

Although it is obvious that overbreadth doctrine carries both benefits and costs, it may be less obvious just what those benefits and costs are and how far they are subject to adjustment and control. A brief survey will help to define the framework within which the crucial choices ought to occur. ${ }^{192}$

\section{A. Factors Supporting an Expansive Overbreadth Doctrine}

Two types of concern support expanding First Amendment overbreadth doctrine beyond its constitutional core. The familiar concept of chilling effect captures the first. ${ }^{193}$ As philosophers and legal theorists have demonstrated, the First Amendment protects rights that are valued for their relationship both to our concept of autonomous personhood ${ }^{194}$ and to our democratic form of government. ${ }^{195}$ First Amendment rights are therefore special, and any chill of their exercise gives rise to extraordinary constitutional concern. ${ }^{196}$ The second element underlying overbreadth doctrine, which is by no means unrelated to the first, involves "concern that an impermissible delegation of authority opens the danger of "selective enforcement against unpopular causes." "197 When a statute sweeps more broadly than is warranted by the evil at which it aims, a concern arises that the legislature has sought to pursue forbidden ends, or that it has created an excessively capacious cloak of administrative or prosecutorial discretion, under which discriminatory enforcement may be hidden. ${ }^{198}$ This theme sounds most explicitly in standardless licensing cases, ${ }^{199}$ but is by no means so limited. The concern echoes through cases as

192. Much of my argument concerning the proper contours of First Amendment overbreadth doctrine would support a doctrine of equal sweep in cases involving alleged infringements of other fundamental rights. In general, however, I limit my express argument to First Amendment overbreadth doctrine. There are two reasons for my doing so. First, this is the area where courts and commentators have focused most explicitly on overbreadth issues. It is, accordingly, perhaps the single area where the doctrine is sufficiently defined to admit criticism of its structure and to permit easy consideration of discrete doctrinal reforms. Second, there are ways in which the First Amendment is, indeed, special. The First Amendment, more even than other constitutional provisions conferring fundamental rights, contributes vitally to the preservation of an open, democratic political regime, at the same time as it secures rights of high importance to particular individuals.

193. See, e.g., Note, supra note 8 , at 846 (calling concern for chilling effect "dynamo of the overbreadth doctrine").

194. See, e.g., L. TRIBE, supra note 24, \& 12-1, at 787-88; Scanlon, $A$ Theory of Free Expression, 1 PHIL. \& PUB. AFF. 204 (1972).

195. See, e.g., A. MEIKLEJOHN, FREE SPEECH AND ITS RELATION TO SELF-GOVERNMENT (1948); Kalven, The New York Times Case: A Note on "The Central Meaning of the First Amendment," 1964 SuP. CT. REV. 191.

196. See, e.g., Osborne v. Ohio, 110 S. Ct. 1691, 1699 n.12 (1990) (quoting Dombrowski v. Pfister, 380 U.S. 479,486 (1965)).

197. Torke, supra note 82, at 295 (quoting NAACP v. Button, 371 U.S. 415, 433 (1963)).

198. See, e.g., City of Lakewood v. Plain Dealer Pub. Co., 486 U.S. 750, 757-69 (1988); Board of Airport Comm'rs v. Jews for Jesus, 482 U.S. 569, 576 (1987); Note, supra note 86, at 80-85.

199. See, e.g., City of Lakewood, 486 U.S. at 757-69. 
seemingly diverse as Board of Airport Commissioners v. Jews for Jesus, ${ }^{200}$ involving an open-ended statute forbidding all "First Amendment activities" within an airport's terminal area, and Shelton $v$. Tucker, ${ }^{201}$ in which a state had demanded that teachers in the public schools divulge the names of all organizations to which they had belonged within a five-year period. Because discrimination based on the content of speech and association is constitutionally suspect, statutes that might mask such discrimination deserve to be treated as suspect also, even in cases in which the fact of discriminatory application is impossible to prove.

The significance of the interests in averting chill and in forestalling discriminatory law enforcement is seldom doubted. It is a separate question, however, how well piophylactic overbreadth doctrine advances these interests, or whether these interests require the extraordinary protection of prophylactically justified rules.

Especially insofar as it is conceived as an instrument for the elimination of chilling effect, overbreadth doctrine functions somewhat crudely. In order to be "chilled" at all, citizens must know how a state statute is written, and some commentators are skeptical of how much awareness of this sort exists. ${ }^{202}$ Moreover, the courts generally assume that a narrowing construction will cure any chilling effect to which a statute gives rise. ${ }^{203}$ While it is somewhat dauntless to assume that citizens are sufficiently aware of what is in the statute book to be chilled by its contents, the assumption that any chill thus created could be eliminated by citizens' awareness of the limiting constructions offered by state courts seems, in many cases at least, positively heroic. ${ }^{204}$ Finally, even if someone knew the law perfectly, it is doubtful how much a federal court's finding that a statute was overbroad-the "strong medicine" that the overbreadth doctrine licenses-would alleviate fear of subsequent sanctions. The uncertainty surrounding the protective effect of such determinations serves as a nagging embarrassment to the argument that overbreadth doctrine helps to alleviate chill. ${ }^{205}$

These concerns undoubtedly warrant some qualification, though not the abandonment, of the argument that prophylactic overbreadth doctrine effectively advances its underlying values. In thinking about the doctrine's effectiveness,

200. 482 U.S. at 576.

201. 364 U.S. $479,486-87$ (1960).

202. See, e.g., Redish, supra note 2, at 1040-41; Note, Overbreadth Review and the Burger Court, 49 N.Y.U. L. REV. 532, 546 (1974).

203. See, e.g., Osborne v. Ohio, 110 S. Ct. 1691,1699 n.12 (1990) ("[o]nce a statute is authoritatively construed, there is no longer any danger that protected speech will be deterred").

204. Cf. Jeffries, Legality, Vagueness, and the Construction of Penal Statutes, 71 VA. L. REV. 189, 208 (1985) (knowledge of law frequently "must be recovered from sources so various and inaccessible as to render the concept (of what constitutes fair and effective notice to the citizen] distinctly unrealistic"). 205. See supra Section IV.A. 
it is helpful to distinguish its ex post and its ex ante effects. ${ }^{206}$ The doctrine's ex post effects occur in situations in which a state legislature has enacted an overbroad statute, no state court has yet narrowed it, and a challenger comes before a court to argue that the law is unconstitutionally overbroad. Assume first that the challenge occurs in a state court. Although I have talked mostly about the overbreadth doctrine as applied by federal courts, the Supreme Court's decisions bind state courts as well. ${ }^{207}$ In cases in which state courts cannot furnish constitutionally adequate narrowing constructions, federal overbreadth doctrine obligates those courts to hold state statutes invalid. ${ }^{208}$ Insofar as the aim of overbreadth doctrine is to eliminate statutes that reflect or threaten to mask constitutionally impermissible purposes, a holding by the state's highest court that a state statute is overbroad will have immediate effect. The state court's decision will have rendered the statute not only unenforceable but, in all probability, unsalvageable. ${ }^{209}$

If the state court instead furnishes a narrowing construction, commentators have questioned how effective the decision will be in alleviating chilling effect. ${ }^{210}$ Indisputably, however, the court's decision will prove beneficial to those citizens who happen to know the law, or who seek professional advice about their legal rights. ${ }^{211}$ Although some skepticism about the size of this class is in order, seldom will it be nonexistent, and in some cases it may be large. Much depends on the nature of the statute involved. Neither statutory text nor a narrowing construction seems likely to affect much of the behavior targeted by a statute prohibiting the use of opprobrious language. ${ }^{212}$ Speech of this kind is too likely to be spontaneous and emotional to allow much time for consideration of consequences or for legal research. On the other hand, an overbroad statute prohibiting public employees from engaging in any form of political activity might well deter action by people fearful of losing their jobs. Moreover, when a statute of this kind is involved, there are likely to be unions or other organized constituencies prepared not only to solicit legal counsel, but to prosecute suits for injunctions and declaratory judgments, and

206. See Massachusetts v. Oakes, 109 S. Ct. 2633, 2639 (1989) (Scalia, J., concurring in the judgment and dissenting in part).

207. See New York v. Ferber, 458 U.S. 747, 767 (1982); Bigelow v. Virginia, 421 U.S. 809, 817 (1975).

208. See, e.g., Commonwealth v. Oakes, 401 Mass. 602, 518 N.E.2d 836 (1988), vacated sub nom. Massachusetts v. Oakes, 109 S. Ct. 2633 (1989).

209. It is conceivable that a state court, in holding a statute unenforceable on the ground that no constitutionally adequate narrowing construction could be reached on the facts of the case before it, would not mean to preclude the possibility of truncating the statute through a series of noncriminal proceedings involving varied fact situations. See infra note 218 . As a practical matter, however, this seems unlikely.

210. See supra notes 202-05 and accompanying text.

211. After a state criminal statute had been narrowed by judicial construction, any subsequent "broadening" by judicial decision in the course of a prosecution would run afoul of the fair notice requirement of the due process clause. See Connally v. General Constr. Co., 269 U.S. 385, 391 (1926) (lack of notice of what conduct state will subsequently prosecute as criminal "violates the first essential of due process of law").

212. See, e.g., Gooding v. Wilson, 405 U.S. 518 (1972). 
to disseminate information about the outcome. Nor is this an isolated case. Fearful of legal sanctions, some people and organizations not only solicit legal counsel, but are even prepared to prosecute suits for injunctions and declaratory judgments before engaging in particular forms of speech or expressive conduct. Indeed, it is not far-fetched to imagine that there are many cases in which those whose conduct is most subject to chill will number among those who are most knowledgeable about decisional as well as statutory law.

Moreover, the benefits of a state court's narrowing construction in advancing constitutional values may sometimes extend to those who know nothing of the legal judgment. For example, when a state court furnishes a construction that identifies the outer reaches of a statute in terms of a bright-line rule of constitutional privilege, that rule may give clear and effective notice to police, prosecutors, and lower court judges that certain forms of speech or conduct are beyond the law's actual as well as its permissible reach. ${ }^{213}$ Narrowing constructions, as induced by federal overbreadth doctrine, may thus help to prevent harassing threats or discriminatory prosecutions in cases in which the government could not lawfully obtain a conviction. Similar benefits may accrue when a state court narrows an apparently standardless licensing statute. ${ }^{214} \mathrm{~A}$ judicial opinion may give officials their first meaningful instructions about the permissible bounds of their discretion. If such officials execute their responsibilities in good faith, their behavior may change significantly, and more protected expression may be licensed at the administrative level.

The effects of an overbreadth ruling admittedly grow more doubtful when a federal court enters the judgment. Nonetheless, in probing the strength of overbreadth medicine, I have not meant to suggest that federal judgments lack power to alleviate, if not wholly to eliminate, chill. Despite the uncertainties discussed above, a federal judgment of overbreadth may well give enforceable legal protection to conduct of parties occurring prior to a state's obtaining an adequate narrowing construction. ${ }^{215}$ Moreover, the lack of a definitive pronouncement notwithstanding, I know of no instance in which a state has brought a successful prosecution against the party who had prevailed in a suit for an injunction or declaratory judgment, for conduct that occurred under the protection of a final and unappealed federal judgment.

Nonparties raise different issues. Even in their case, however, the argument is strong, albeit uncertain, that a Supreme Court judgment of overbreadth would protect conduct occurring prior to a state court's confinement of a statute to constitutional bounds. ${ }^{216}$ Further, it merits notice that state court narrowing

213. Cf. Jeffries, supra note 204, at 222-23 (arguing that bright-line constructions of criminal statutes are helpful in constraining behavior of enforcement-level officials and thus in keeping such officials within rule of law).

214. See, e.g., Shuttlesworth v. City of Birmingham, 382 U.S. 87 (1965); Cox v. New Hampshire, 312 U.S. 569 (1941).

215. See, e.g., Shapiro, supra note 4, at 769.

216. See infra note 275 and accompanying text. 
constructions, although available in theory, may be hard to obtain in practice. Following a Supreme Court determination that a state statute is overbroad, prosecutors may perceive the enterprise of achieving the necessary trimming through a series of state court actions-in which state courts, as noted above, ${ }^{217}$ are required to follow federal overbreadth doctrine-as too risky and time-consuming to be worth the effort. ${ }^{218}$ Even in cases in which the federal declaration of overbreadth comes from a lower federal court, state prosecutors may hesitate to bring subsequent prosecutions in state court. The federal judgment may make a persuasive case that the statute is too broad to be enforced and that no bright-line narrowing construction suggests itself. If so, prosecutors could achieve a more contoured pruning only through a lengthy sequence of declaratory judgment actions, and they may think the game not worth the candle. Whatever the explanation, there are few recent, reported cases in which a state statute held unconstitutionally overbroad by a federal court has been subsequently enforced in a state court action. ${ }^{219}$

A final set of arguments in favor of a robust overbreadth doctrine, which Justice Scalia has characterized as ex ante, ${ }^{220}$ emphasizes the effect that such a doctrine is likely to have on state legislatures. The knowledge that an overbroad statute may be declared invalid by either a state or federal court, with serious attendant consequences, functions as an incentive to legislatures to write narrower statutes in the first instance when regulating speech and expressive activity. ${ }^{221}$

217. See supra notes 207-08 and accompanying text.

218. In a state criminal prosecution or other coercive action, a state court would need either to supply a constitutionally adequate interpretation of a facially overbroad statute or to dismiss the action on grounds of overbreadth. In a declaratory judgment action such as the Supreme Court contemplated in Dombrowski v. Pfister, 380 U.S. 479, 492 (1965), however, a state court apparently would not need to provide a comprehensive interpretation of the statute, but could narrow it by providing what Professor Monaghan has termed a "contextually specific construction" in "a negative form." Monaghan, supra note 3, at 29 \& n. 119. For example, it apparently could say: "the statute may constitutionally be applied to this set of facts, because the First Amendment does not include a right to engage in the conduct in which the defendants were engaged, and the statute should be understood to sweep no further than the First Amendment privilege rule that the defendants erroneously claim to be protected by." The difficulty with this approach, from the perspective of state prosecutors, is that it frequently would be "fictional to believe that anything less than extensive adjudications, under the impact of a variety of factual situations, would bring [a statute] within the bounds of permissible constitutional certainty." Baggett v. Builitt, 377 U.S. 360, 378 (1964), quoted in Board of Airport Comm'rs v. Jews for Jesus, 482 U.S. 569, 575 (1987).

219. My own research uncovered 45 cases, decided between June 1, 1985 and June 1, 1990, in which lower federal courts held state statutes unconstitutionally overbroad, but only three cases-two involving the same statute-in which state prosecutors, following federal holdings of overbreadth, brought actions to enforce the affected statutes. In other words, of the 45 statutes held unconstitutional, 43 have been so treated by state prosecutors, so far as published judicial reports reveal. This sample suggests, though it does not prove, that overbreadth holdings by lower federal courts may be far more potent in practice than the surrounding legal doctrines would require them to be.

220. See Massachusetts v. Oakes, 109 S. Ct. 2633, 2639 (1989) (Scalia, J., concurring in the judgment and dissenting in part).

221. See Osborne v. Ohio, 110 S. Ct. 1691, 1702 (1990); Oakes, $109 \mathrm{~S}$. Ct. at 2639. This argument rests on two assumptions about legislative psychology, one of which is likely to be controversial and the other of which is not. It should be relatively obvious that legislatures frequently respond to the threat that a statute may be invalidated on grounds of overbreadth. For example, after the Supreme Court formulated 
Conceding that overbreadth doctrine is at least somewhat effective in promoting its underlying values of averting chill and discriminatory law enforcement, a skeptic might still object that the prophylactic element of the doctrine is unnecessary and that what I have described as the doctrine's constitutionally mandated, rule-of-law core confers protection enough. But this argument founders on the recollection of how narrow that core turns out to be upon critical probing. ${ }^{222}$ If overbreadth doctrine were limited to protecting the personal right not to be subjected to sanctions under an unconstitutional rule of law, sanctions should be sustained even under overbroad statutes so long as (i) the statutes are severable and (ii) the proof and jury instructions sufficiently establish that the defendant's personal conduct was not constitutionally protected. This approach would virtually never require a court, either state or federal, to invalidate a statute - as opposed to dismissing a particular prosecution or vacating or reversing an individual conviction-on grounds of overbreadth. ${ }^{223}$ As a result, an overbreadth doctrine limited to the minimal requirements of the rule of law would create no significant incentive for legislatures to draft precisely, nor would it require courts to give narrowing judicial constructions that are adequate to provide clear, rule-like notice of a statute's effective reach.

a definition of prohibitable obscenity in Miller v. California, 413 U.S. 15 (1973), thirty-seven state legislatures revised their statutes to incorporate the Miller definition. See New York v. Ferber, 458 U.S. 747,755 n.7 (1982). In the debates leading to the adoption of the Miller standard by the Massachusetts legislature, to cite just one example, proponents of the proposed legislation defended it, and resisted amendments, on the grounds that a broader definition of obscenity would "create constitutional doubt" about the bill, Massachusetts State House News Service, Transcript of General Court Debates, April 30, 1974, at 13 (unofficial and abbreviated version) (remarks of Rep. Leblanc), and that "it does no good to adopt" overbroad legislation, Massachusetts State House News Service, Transcript of General Court Debates, May 16, 1974, at 11 (remarks of Rep. Moleson). Federal legislators have expressed similar concerns. See H.R. REP. No. 696, 95th Cong., 1st Sess. 6-8; S. REP. No. 438, 95th Cong., 1st Sess. 11-15, reprinted in 1978 U.S. CODE CONG. \& ADMIN. NEWS 40, 48-52 (explaining that House and Senate committees, in drafting the legislation that became The Protection of Children Against Sexual Exploitation Act of 1977, had rejected further-reaching language on ground that it would be overbroad under the Miller standard).

The more controversial assumption is that the threat of a statute's being invalidated, and of the consequent loss of opportunities to punish antisocial conduct, functions as an incentive independent of a presumptive concern on the part of legislators to adhere to constitutional norms simply because the Constitution, as interpreted by the Supreme Court, is the fundamental law. The assumption that the threat of sanctions creates an effective motive for adherence to legal norms is of course a familiar one, whose general validity is not in doubt. See, e.g., R. POSNER, ECONOMIC ANALYSIS OF LAW 3, 491 (3d ed. 1986) (asserting that legal system operates through imposition of incentives in form of sanctions against certain kinds of behavior). Legislators, however, might be thought to be either above the need for sanctions, because they are so highly conscientious, or impervious to the sanction of an overbreadth ruling, since they personally would not bear any direct cost. My own instinct, which I can describe but not otherwise validate, is to assume that legislatures generally try to conform to constitutional standards, and would do so even if serious costs were not involved. With respect to legislation that tends to stir deep emotions (e.g. the regulation of child pornography), however, the threat of an overbreadth invalidation may sometimes be important, at least for some legislators. It is at least plausible to think that in such cases legislators may be tempted to overreach, possibly because they conscientiously believe that the Supreme Court has erred in overprotecting antisocial conduct. They may also, however, be sufficiently concerned about the consequences of overreaching-in the form of foregone opportunities to regulate and punish antisocial conduct-to alter their voting dispositions in light of First Amendment overbreadth doctrine.

222. See supra notes $105-24$ and accompanying text (discussing Professor Monaghan's efforts to develop a broader account).

223. See supra text accompanying notes $125-28$. 


\section{B. Costs of an Expansive Overbreadth Doctrine}

Although the benefits of a prophylactic overbreadth doctrine are real, the costs can also be high. The costs take two forms. One involves the possible overdeterrence of state legislatures. Fearful of the consequences of having a statute declared unconstitutionally overbroad, legislatures may draft laws with overabundant caution. If they are intimidated into withholding sanctions even from constitutionally prohibitable expressive activity - the production and dissemination of certain forms of child pornography, for example—legislatures may fail to deal effectively with pressing social problems. A second kind of cost, which arises when a court holds a state statute unconstitutional under the prophylactic element of overbreadth doctrine, encompasses what the judicial ruling forces the state to forego: a greater or lesser number of opportunities to impose sanctions for conduct that the state legislature wanted to prohibit and that is not itself constitutionally protected. Federal decisions that deprive states of opportunities to sanction constitutionally unprotected conduct may be especially regrettable in the context of American federalism. In order to hold a state statute unconstitutionally overbroad, a federal court must first determine what the statute means as a matter of state law. ${ }^{224}$ Inevitably, some determinations of overbreadth will involve federal judicial errors.

Though often decried, the costs of First Amendment overbreadth doctrine have seldom if ever been calibrated. Courts and commentators have paid too little attention to the precise legal effect of an overbreadth holding, either in the case in which it is rendered or in other cases involving the same statute. ${ }^{225}$ It is at least partly for this reason that so many questions about the protective scope of federal determinations of overbreadth, as discussed above, ${ }^{226}$ remain unsettled. In any case, the question of the protective effect of a federal judgment is one of federal law, ${ }^{227}$ and the Supreme Court possesses substantial discretion to shape the answer to accommodate concerns of policy. ${ }^{228}$ Here, then, I put aside questions of what the law is and consider some possibilities as to what it might be. For heuristic purposes, it may prove useful to schematize, in ascending order of severity, four possible effects of a federal court's overbreadth holding and the attendant costs to the state: ${ }^{229}$

(i) The individual challenging the statute might be held immune from sanction thereunder until a successful narrowing construction is obtained, but

224. See Shapiro, supra note 4 , at $766-67$.

225. There are notable exceptions. See, e.g., HART \& WECHSLER, supra note 13, at 1423-28; Shapiro, supra note 4.

226. See supra Part IV.

227. See supra note 5.

228. On the extent to which the effects of holdings of statutory voidness and unconstitutionality are generally shaped by policy concerns, see Note, supra note 7 .

229. I put aside for the moment questions about the relevance of distinctions between the Supreme Court and lower federal courts and among the contexts in which the judgment might be entered. 
the judgment might contemplate that a narrowing construction could emerge in further proceedings in the same case. For example, in a criminal case being reviewed in the Supreme Court, the Court might vacate the conviction, indicate where the relevant statute overstepped constitutional bounds or otherwise indicate how the statute might be saved, and remand the case. The state's highest court could then reconsider its interpretation in light of the Supreme Court's constitutional pronouncement. ${ }^{230}$ Of all the costs that might be imposed, this would be the most minimal. Although entailing time-consuming procedures, it would not necessarily deprive the state of the opportunity to vindicate its statutory policy in even a single case.

(ii) The individual challenging the statute might be held immune from sanction thereunder for any conduct occurring before the state obtains a constitutionally adequate narrowing construction, but the state might be left free to proceed against nonparties, in whose cases narrowing constructions might be sought. The Supreme Court seems to have taken an approach similar to this in at least two cases involving omnibus disorderly conduct statutes, Cantwell $v$. Connecticut ${ }^{231}$ and Cox v. Louisiana. ${ }^{232}$ In both the Court suggested that the relevant statutes were intolerably overbroad. ${ }^{233}$ In both it accordingly reversed convictions. Yet in neither case did the Court suggest that the state should be disabled from proceeding against other defendants. Indeed, a year after Cox, in Brown v. Louisiana, ${ }^{234}$ a plurality of the Court reversed another conviction under the same statute, not because the statute was invalid on its face, but because the record demonstrated "no violation of the statute" by petitioners who were engaged in constitutionally privileged activity. ${ }^{235}$

(iii) All conduct that occurs after the determination of overbreadth, and prior to the time that prosecutors obtain a constitutionally adequate narrowing construction, might be immunized from sanction. Although the state might get a narrowing construction, and prosecute conduct occurring subsequently, it could not penalize conduct engaged in by any person, party or nonparty, before the courts provided a narrowing construction. This result, which the Dombrowski dictum ${ }^{236}$ appears to contemplate in at least some cases in which the state obtains a narrowing construction, but in which "notice" problems would make it unfair to prosecute prior conduct, would impose a considerable, but less than maximal, cost upon the state.

230. See, e.g., Time, Inc. v. Hill, 385 U.S. 374, $394-97$ (1967) (holding that jury instructions interpreting statute rendered it unconstitutionally overbroad, but, instead of reversing judgment on overbreadth grounds, vacating and remanding case for further proceedings in which constitutionally adequate interpretive instruction might be given); $c f$. HART \& WECHSLER, supra note 13, at 190 (suggesting this as possible disposition).

231. 310 U.S. 296 (1940).

232. 379 U.S. 536 (1965).

233. See Cox, 379 U.S. at 551; Cantwell, 310 U.S. at 308, 311.

234. 383 U.S. 131 (1966).

235. Id. at 141 (Fortas, J., plurality opinion).

236. See supra text accompanying note 149 . 
(iv) The state could not impose sanctions on any conduct that occurred prior to the provision of a constitutionally adequate narrowing construction of an overbroad statute. Not only would this approach stop enforcement of the statute; to the extent that doctrines limiting post-conviction relief allow, ${ }^{237}$ the state would lose all criminal convictions that it might have obtained before the determination of overbreadth. ${ }^{238}$

This list of possible effects of a prophylactic overbreadth holding is obviously partial and crude. Many more possibilities exist. The recitation of possible consequences fails to distinguish between civil and criminal statutes. Nor does the list reflect the distinction, which I introduced earlier and to which I shall return shortly, between a Supreme Court determination of overbreadth in an enforcement action and a lower federal court's holding in a suit for anticipatory relief. But I believe that the list is useful nonetheless, for two reasons. First, however simplistic it may be, this schematized tally of possible effects helps to make vivid that a range of choice exists regarding the practical effect of prophylactic overbreadth doctrine. Second, the list should help to make intuitively clear something that is likely to be true of any more refined and comprehensive list: however the effects are arrayed along a spectrum, there is likely to be a felt disjunction between those remedial effects, such as (i) and (ii) above, that are relatively inexpensive to the state, since they cause the state to forego imposition of sanctions in few if any cases, and more powerful effects, such as (iii) and (iv), that subject the state to a considerable cost, measured in lost opportunities to impose penalties for anti-social conduct.

\section{Toward a Balance}

With the potential benefits and costs now sketched, the foundation exists for an interim conclusion: the benefits of a prophylactically based overbreadth doctrine would at least sometimes outweigh the appropriately calibrated costs. Standing alone, the likely benefits of a robust doctrine are significant, especially in cases involving those categories of overbroad statutes that are most likely to reflect content-based official hostility to protected expressive activity. On the other side of the balance, the costs are real, and might sometimes be felt as intolerable. But, significantly, the costs themselves are susceptible to calibration and adjustment. To say this is not, I should emphasize, to suggest that the effects of an overbreadth holding should never be made costly to the state. On the contrary, some reasonably heavy price must be exacted if the threat of invalidation is to create significant incentives for state legislatures to enact precisely drawn statutes and for state courts, where necessary, to supply narrowing constructions. The point, rather, is that the strength of the over-

237. See supra note 13 and accompanying text.

238. Although rebuffed by Justice White's majority opinion, the appellant seems to have contended for this result in Osborne v. Ohio, 110 S. Ct. 1691, 1702-03 (1990). 
breadth medicine can and should be reasonably proportionate to the ill that it is intended to cure. I emphasize the interim character of the conclusion that a prophylactic overbreadth doctrine should be retained and implemented because the most crucial work remains to be done. It remains to specify how strong the overbreadth medicine ought to be and in which cases it should be applied.

\section{SHAPING A BETTER DOCTRINE}

The appropriate structure of First Amendment overbreadth doctrine depends on the answers to two hard questions. First, when should statutes be held overbroad? Second, what, among the array of possible choices, should the consequences of such a holding be?

\section{A. Measuring Substantial Overbreadth}

The Supreme Court has held that a federal court should invalidate a state statute for overbreadth only if the statute is "substantially" overbroad. ${ }^{239}$ At some level of generality, this requirement surely makes good sense with respect to prophylactic overbreadth. ${ }^{240}$ If the Constitution does not mandate overbreadth invalidation as a matter of personal right, and if the overbreadth is so insubstantial that there is little by way of narrowing that a state legislature or state court could reasonably do, a federal court should not administer overbreadth medicine. ${ }^{241}$ It affords sufficient protection to First Amendment values to hold a statute invalid only as applied to constitutionally privileged conduct.

Another element of settled doctrine similarly deserves retention: A federal court should generally not hold a state statute overbroad if a constitutionally adequate narrowing construction suggests itself. ${ }^{242}$ Overbreadth medicine makes sense only when a cure would be difficult to effect through narrowing judicial constructions. This degree of federal forgivingness could imaginably reduce legislatures' incentive to draft narrow laws, but not by much. If a legislature passes an overbroad statute, it risks that its handiwork will be held overbroad, either by a state or a federal court, with some significant cost imposed. ${ }^{243}$

The hard question, normatively as well as doctrinally, is how the substantiality of a statute's overbreadth ought to be gauged. The Supreme Court has

239. See, e.g., Osborne v. Ohio, 110 S. Ct. 1691 (1990).

240. Cf. Broadrick v. Oklahoma, 413 U.S. 601, 630 (1973) (Brennan, J., dissenting) (recognizing that Court had "never held that a statute should be held invalid on its face merely because it is possible to conceive of a single impermissible application, and in that sense a requirement of substantial overbreadth is . . . implicit in the doctrine").

241. See Note, supra note 8 , at 858-60.

242. See, e.g., Erznoznik v. City of Jacksonville, 422 U.S. 205, 216 (1975); Dombrowski v. Pfister, 380 U.S. 479,497 (1965).

243. See, e.g., Osborne, 110 S. Ct. at 1702. 
occasionally tried to express the substantiality requirement in terms of a geometric proportion. The proper comparison, it has suggested, is between the number of cases to which a court might constitutionally apply a statute, and the number of cases in which the statute's application would violate constitutional rights. ${ }^{244}$ Among its deficiencies, this approach calls for uncabined judicial speculation in areas that are, at best, on the outer fringes of the courts' practical competence. Massachusetts v. Oakes ${ }^{245}$ illustrates the difficulty. Agreeing that a statute prohibiting the production or distribution of photographs of children in particular forms of partial nudity was overbroad, Justices Brennan and Scalia had to reach the question of substantiality. For both, the issue was largely one of how many family photographs existed of, for example, naked toddlers on the beach. Justice Brennan concluded that there would be many such cases relative to the statute's permissible applications. ${ }^{246}$ Justice Scalia reached the opposite conclusion. ${ }^{247}$ But neither, understandably, was able to furnish anything approaching a numerical estimate-much less a reliable numerical estimate - of how many acts by how many people, in any particular year, the statute might permissibly and impermissibly reach.

There is no sensible substitute, at least in hard cases, for a forthright judicial balancing. ${ }^{248}$ Since the substantiality issue does not arise except in cases that lie beyond overbreadth doctrine's constitutional core, the question of when overbreadth is intolerably substantial has an irreducible component of policy. In making the determination, the court should weigh (a) the state's substantive interest in being able to impose sanctions for a particular kind of conduct under a particular legal standard, as opposed to being forced to rely on other, less restrictive substitutes ${ }^{249}$ against (b) the First Amendment interest in encouraging narrow statutes and avoiding as much as possible the chilling of constitutionally protected conduct. ${ }^{250}$ The more weighty the state's context-specific interest, the more reluctant a federal court should be to find a statute substantially overbroad. ${ }^{251}$ By similar token, the farther that chilled conduct lies from

244. See, e.g., Osborne, $110 \mathrm{~S}$. Ct. at 1697 (substantiality of statute's overbreadth should be "judged in relation to the statute's plainly legitimate sweep") (quoting Broadrick v. Oklahoma, 413 U.S. 601, 615 (1973)).

245. 109 S. Ct. 2633 (1989).

246. See id. at 2645.

247. See id. at 2641.

248. See Redish, supra note 2 , at $1066-69$.

249. This is a version of the familiar less-restrictive-alternatives analysis, see Note, Less Drastic Means and the First Amendment, 78 YALE L.J. 464 (1969), that is likely to be used "wherever the Supreme Court is serious about judicial review." Monaghan, supra note 3 , at 38.

250. For a similar formula, see Alexander, Is There an Overbreadth Doctrine?, 22 SAN DIEGo L. REV. 541, 553-54 (1985); see also Redish, supra note 2, at 1066-69 (advocating balancing analysis).

251. One factor that courts should not consider in determining whether a statute is overbroad is the state's interest in retaining the opportunity to prosecute and punish persons who have already engaged in conduct that the state wishes to prohibit. This consideration should be dealt with separately, on a general basis, as part of a principled calculation of what the effects of a holding of overbreadth ought to be. For a discussion of this issue, see infra text accompanying notes 275-303. 
the central concerns of the First Amendment-"commercial"252 and "adult"253 speech are two examples of protected but somewhat marginal categories-the more a federal court should hesitate about declaring a state statute void for overbreadth.

Although analysis of this kind has an irreducibly ad hoc quality, some guidelines may emerge from consideration of the different kinds of overbroad statutes that were discussed in Part II.

(i) When a state regulates or burdens speech on the basis of content in order to advance an interest that the state deems compelling, balancing-under a formula such as that outlined above-is unavoidable. The court must inquire whether the state's interest is truly compelling, and, if so, whether that interest justifies as much infringement on, and chilling of, protected speech as the statute effects. Although reluctant to acknowledge that it is doing so, the Supreme Court seems to have employed a balancing approach of this sort in recent cases. In City of Houston v. Hill, ${ }^{254}$ for example, the Court invalidated as overbroad an ordinance that made it a crime to "willfully or intentionally interrupt a city policeman ... by verbal challenge during an investigation."255 In doing so, the Court noted the availability of less restrictive alternatives-such as prohibitions aimed at physical harassment and fighting words-to protect many of the City's legitimate interests. ${ }^{256}$ Beyond that, the Court seemed to accept that its ruling might effectively require some constitutionally unprotected speech to go unpunished. ${ }^{257}$ But it remained insistent that this price be paid. Within the terms of a balancing test, the Court thought that any imaginable ordinance that effectively barred all unprotected speech would also sweep in and thereby chill too much constitutionally privileged speech that was too precious in value. This analysis plainly had a qualitative as well as a quantitative dimension. The Court brought into the balance its view that " $[\mathrm{t}]$ he freedom of individuals verbally to oppose or challenge police action without thereby risking arrest is one of the principal characteristics by which we distinguish a free nation from a police state."258

(ii) In cases in which a state aims to proscribe speech within a constitutionally unprotected category, the crucial question will often be whether the state has exceeded the bounds of an extant Supreme Court definition (whether, for example, it has gone beyond the Court's definition of the category of obscenity or of fighting words). If the state has gone too far, a less restrictive alternative

252. See, e.g., San Francisco Arts \& Athletics, Inc. v. United States Olympic Committee, 483 U.S. $522,536 \mathrm{n} .15$ (1987) (noting that "the application of the overbreadth doctrine [to commercial speech] is highly questionable").

253. See City of Renton v. Playtime Theatres, Inc., 475 U.S. 41 (1986); Young v. American Mini Theatres, Inc., 427 U.S. 50 (1976).

254. 482 U.S. 451 (1987).

255. Id. at 454 .

256. Id. at 462 n.11.

257. Id.

258. Id. at 462-63. 
is presumably available, and it should not take much overbreadth in an absolute sense to count as substantial. ${ }^{259}$

Sometimes, however, Supreme Court precedent may provide no precise formula for the identification of prohibitable speech. In Osborne v. Ohio, ${ }^{260}$ for example, the Court confronted a state statute construed to prohibit "the possession or viewing of material or performance of a minor who is in a state of nudity, where such nudity constitutes a lewd exhibition or involves a graphic focus on the genitals." ${ }^{261}$ The state defended its prohibition as limited to the category of "child pornography" that New York v. Ferber ${ }^{262}$ held constitutionally unprotected. Ferber, however, had failed to supply a formulaic specification of the unprotected category, and the Ohio statute involved in Osborne swept somewhat more broadly than the law upheld in Ferber. Although the Court avoided schematizing its analysis in this way, it could not avoid a somewhat open-ended balancing approach. Among the factors appropriately relevant to the decision, the Court noted the extreme importance of the state's interest. ${ }^{263}$ The Court might also have concluded that the value of most of the protected speech chilled by the statute would probably be "exceedingly modest." 264 If so, it would be correct to carve out exceptions for protected conduct only on a case-by-case basis.

(iii) Among the category of statutes that aims to promote state interests unrelated to the content of expression and that infringes First Amendment interests only incidentally, courts should hesitate to find substantial overbreadth. ${ }^{265}$ An anti-trespass law, for example, may affect people trying to communicate their political views, and indeed might imaginably affect a large

259. Cf. Lewis v. City of New Orleans, 415 U.S. 130 (1974) (rejecting argument that state statute applies only to constitutionally unprotected category of "fighting words" when state courts had not construed statute in terms used by Supreme Court to define that category); Gooding v. Wilson, 405 U.S. 518, 522-28 (1972) (same). A court may not, however, be able to avoid a more comprehensive balancing. In using definitions of unprotected categories to measure the permissibility of state statutes, a court must take account of the value of the protected speech that a statute may chill or that may be made the potential target of objectionably discriminatory enforcement efforts. The more likely that speech or its restriction involves central First Amendment values, the more disposed a court should be to classify any overbreadth as substantial. This interpretive principle may help to explain in part the Court's willingness to invalidate statutes that states have defended as intended to proscribe only constitutionally unprotected "fighting words." See Lewis, 415 U.S. 130; Gooding, 405 U.S. at 522-28. As the cases before the Court have demonstrated, such statutes are easily and perhaps commonly applied to those who protest against police and other official behavior. So applied, they may either chill political speech or, what is perhaps more likely and equally anathema to First Amendment values, may result in discriminatory enforcement against speech that has a substantial political component and is identified on the basis of content. Cf. Lewis, 415 U.S. at 136 (Powell, J., concurring); Gooding, 405 U.S. at 528.

260. 110 S. Ct. 1691 (1990).

261. Id. at 1698 (quoting State v. Young, 37 Ohio St. 3d 249, 252, 525 N.E.2d 1303, 1368 (1988)).

262. 458 U.S. 747 (1982).

263. See Osborne, 110 S. Ct. at 1697 \& n.8.

264. Id. at 1695 (quoting Ferber, 458 U.S. at 762).

265. Cf. Note, supra note 8 , at 860 ("[For overbreadth properly to be found,] the area affected by a challenged law must substantially involve First Amendment interests. That is, the primary conduct which is affected by the law at issue must to a substantial extent be the kind of expressive and associational behavior which at least has a colorable claim to the protection of the amendment."). 
number of people who would like to demonstrate on private property ${ }^{266}$ or on public property reserved for nonexpressive purposes. ${ }^{267}$ But when government has not targeted expressive activity, courts cannot reasonably require a regulation to achieve the degree of precision that is warranted when a law centrally implicates speech. Only a small likelihood will typically exist that the statute reflects a covert effort to discriminate on the basis of content. Moreover, the government's valid interest in being able to enforce the statute will frequently be important. If the judicial focus broadens beyond the facts of a particular case within this category, it most appropriately does so to draw lines identifying constitutionally privileged conduct that is immune from regulation. ${ }^{268}$ Judicial determinations of this kind emerge most naturally and appropriately from cases involving conduct with a plausible claim of privilege, not disputes in which a challenger whose own conduct is clearly unprotected raises a claim of overbreadth.

The Supreme Court's decision in NAACP v. Button ${ }^{269}$ illustrates this approach. At a time when commercial speech did not receive First Amendment protection, the Court held a Virginia barratry law impermissibly overbroad, but only as applied to the politically oriented litigating efforts of the NAACP. In practical effect, it was as though the Court had upheld the law against an overbreadth challenge, but ruled that it would be unconstitutional as applied to group activity associated with politically motivated litigation. In light of the understanding that ordinary forms of barratry lay wholly outside the First Amendment, this ruling would not have been appropriate in a case brought by a party whose conduct was not at least arguably constitutionally privileged.

(iv) Standardless licensing statutes pose special threats to First Amendment values, because they tend to mask invidious discrimination and thus to insulate it from judicial review. ${ }^{270}$ Where no standards are provided at all, invalidation on overbreadth grounds should follow unproblematically. Matters will not often be that simple, however. When the state's interest in licensing is ostensibly unrelated to the content of the regulated speech, the hard issue, concerning which the overbreadth rubric offers little guidance, involves the standards of specificity to which the state might reasonably be held. Consider, for example, the difficulty of developing specific criteria governing the granting or withholding of permits to parade along particular routes at particular times. Reflecting its sense of practical possibilities, the Supreme Court has upheld a standard directing the issuance of permits only when "the convenience of the public in the use of the streets would not thereby be unduly disturbed."271

266. See, e.g., Marsh v. Alabama, 326 U.S. 501 (1946).

267. See, e.g., Greer v. Spock, 424 U.S. 828 (1976); Adderley v. Florida, 385 U.S. 39 (1966).

268. See Note, supra note 8 , at 861 .

269. 371 U.S. 415 (1963).

270. See, e.g., City of Lakewood v. Plain Dealer Pub. Co., 486 U.S. 750, 757-69 (1988).

271. Cox v. New Hampshire, 312 U.S. 569, 576 (1941); see also Shuttlesworth v. City of Birmingham, 394 U.S. 147, 154-55 (1969). 
At the level of specific holdings, the Court can be criticized for demanding too little. The potential for discretionary denials under this standard remains vast. Moreover, as Professor Blasi has shown, governments can write ordinances regulating parade permits that possess a good deal more determinacy. ${ }^{272}$ At another level, however, the Court's approach is surely correct. Licensing systems have long attracted vilification, and rightly so. But sometimes, as in the case of parade permits, licensing requirements are reasonable and appropriate. If more specificity were not reasonably possible, worries about overbreadth and abusable discretion would have to yield to Professor Kalven's "unbeatable proposition that you cannot have two parades on the same corner at the same time."273 There is, in short, no short answer to the question of when a licensing system should be invalidated on grounds of overbreadth. Context-sensitive balancing is required and, properly conducted, would include such features as the adequacy of statutorily prescribed judicial review provisions. ${ }^{274}$

\section{B. The Potency of the Overbreadth Medicine}

In considering the shape that overbreadth doctrine ought to assume, this section addresses a series of large questions concerning the potency that overbreadth determinations ought to enjoy. I first discuss overbreadth determinations rendered by the Supreme Court in reviewing cases brought to enforce state laws in state court. I then turn to potency and related issues that arise in connection with declaratory judgment and injunctive actions in the lower federal courts.

\section{Supreme Court Review of State Enforcement Actions}

In order for the threat of an overbreadth "invalidation" to have the desired incentive effects on state courts and state legislatures, the implications of an overbreadth holding must be significant. Accordingly, it would seldom suffice to limit the benefits of a prophylactic overbreadth holding to the party to the lawsuit before the court. To draw from the list of possible effects noted in Section V.B., a variant of (iii) strikes the proper balance: the state should be barred from prosecuting anyone for conduct that occurs from the time of the invalidation until after it obtains a narrowing construction. Although I would extend the benefits of this rule to anyone in whose case a judgment had not yet become final at the time of the federal court's ruling, there should be no need, as option (iv) contemplates, to reopen settled civil cases, or for the jail

272. Blasi, Prior Restraints on Demonstrations, 68 MiCH. L. REV. 1481, 1484-1534 (1970).

273. Kalven, The Concept of a Public Forum: Cox v. Louisiana, 1965 SUP. Cr. REv. 1, 25.

274. See, e.g., Blasi, supra note 272, at 1534-35; Monaghan, supra note 94, at 241-43. 
doors to swing open, except insofar as the rule-of-law aspects of overbreadth doctrine might so require. ${ }^{275}$

This proposal makes a Supreme Court determination of overbreadth strong medicine-stronger, for example, than the Court appears to have contemplated in its dictum in the Dombrowski case that, after the state obtains a satisfactory narrowing construction, it might proceed against prior conduct. ${ }^{276}$ The difficulty with that approach is not, as some commentators have worried, that it creates problems of fair notice. ${ }^{277}$ The problem, rather, is that prophylactic overbreadth must have some higher degree of potency to affect the thought and action of state legislatures and state courts in the desired way.

Although the general approach should make overbreadth holdings costly to the state, exceptions might commend themselves in particular kinds of cases-for example, cases in which the Supreme Court's decision reflects an expansion of previously recognized privilege rules that a state court could not reasonably have been expected to anticipate ${ }^{278}$ and in which the Court has identified a bright-line rule of constitutionally privileged conduct that, if incorporated into a state court's saving construction, would bring a statute immediately within constitutional bounds with no need for case-by-case pruning. ${ }^{279}$ If convinced that a justification exists, the Court might specify the permissible outer boundaries of a statute's reach, vacate the judgment, and remand the case to the state court to reconsider its interpretation in light of a corrected understanding of what the federal Constitution requires or permits. The Supreme Court sometimes follows an analogous procedure in other kinds

275. This suggestion is generally consonant with, though not dictated by, the "retroactivity" principles followed in other areas of the law. These principles call for courts to apply newly announced constitutional rules to all nonfinal criminal cases, see Griffith v. Kentucky, 479 U.S. 314, 328 (1987), and in the absence of special circumstances, to nonfinal civil cases, see Chevron Oil Co. v. Huson, 404 U.S. 97, 105-07 (1971), but sharply limit the scope of permissible collateral attacks on judgments that have ripened to finality, see, e.g., Teague v. Lane, 489 U.S. 288, 294-301 (1989).

276. See supra note 149 and accompanying text.

277. See, e.g., Shapiro, supra note 4 , at 769. As noted above, see supra text accompanying notes 152-58, the "fair notice" argument is circular: if the legal rule were clear that the state could subsequently punish conduct occurring prior to a saving construction, everyone would have notice of the state's intent and capacity, provided that it could get an adequate limiting construction, to bring subsequent prosecutions.

278. The Supreme Court has recognized in various contexts that an equitable adjustment of remedies may be appropriate when a decision reflects a clear break from settled law, the new rule's purposes do not require its retroactive application, and retroactivity would have inequitable consequences or an adverse impact on the administration of justice. See, e.g., American Trucking Ass'ns v. Smith, 110 S. Ct. 2323, 2331-33 (1990) (plurality opinion); Chevron Oil Co., 404 U.S. at 106-07.

279. Cf. Time, Inc. v. Hill, 385 U.S. 374, 394-98 (1967) (holding that jury instructions interpreting statute allowed imposition of liability for constitutionally privileged expression, but vacating and remanding case for further proceedings in which constitutionally adequate interpretive instruction, as newly identified in Court's opinion, might be employed). It might of course be asked why, if a bright-line privilege rule so easily suggested itself, the state should not be penalized for failing to write or construe its statute so as to respect that rule. The more easily the Court's constitutional pronouncement might have been anticipated, the more force this argument attains. A departure from standard practice may therefore be relatively more attractive when, as in Time, Inc. v. Hill, and as under the formula suggested in text, the Court's constitutional determination is relatively novel. But $c f$. Kaplow, An Economic Analysis of Legal Transitions, 99 HARV. L. REV. 509 (1986) (arguing that it is socially desirable to create incentives for primary actors to take into account possibility even of relatively unpredictable changes in governing legal framework). 
of cases, when it thinks that a state court's construction of state law might be influenced by an erroneous interpretation of federal law. ${ }^{280}$ This course, however, should mark the exception and not the rule. In general, the implications of a Supreme Court holding of overbreadth should be sufficiently severe to create an incentive for state legislatures and state courts to conform their behavior to First Amendment values.

\section{Anticipatory Actions in the Lower Federal Courts}

As applied by the lower federal courts, First Amendment overbreadth doctrine creates a serious risk of judicial error, since a lower federal court cannot hold a state statute unconstitutional without anticipating the meaning that a state court would assign. This situation contrasts with that obtaining on Supreme Court review of enforcement actions, when the state courts will have furnished an authoritative construction. ${ }^{281}$ In addition, overbreadth challenges are likely to occur more frequently in the lower federal courts than on Supreme Court review. In light of the concern that overbreadth doctrine should not incur costs disproportionate to its benefits, these are strong reasons why the consequences of a lower court's overbreadth ruling in an anticipatory action should be less severe than those of a Supreme Court ruling in an enforcement case. $^{282}$

Against this set of background concerns, analysis of the potency that a lower federal court's determination of overbreadth ought to have requires attention to a series of related questions. I begin with the assumption, explained above, that the preclusive effects of a lower federal court's determination of overbreadth run directly only to the parties to the lawsuit. ${ }^{283}$ But exactly what, with respect to those parties, are the relevant effects? Suppose first that, following a lower federal court's determination of overbreadth, the state obtains

280. See, e.g., Patterson v. Alabama, 294 U.S. 600, 606-07 (1935).

281. Anticipatory actions sometimes occur before the state courts have had the opportunity to fashion a narrowing construction. See, e.g., Board of Airport Comm'rs v. Jews for Jesus, 482 U.S. 569, 575-76 (1987).

282. In general, I assume that a Supreme Court judgment entered on review of a lower federal court's decision in a suit for anticipatory relief should have the same preclusive or privileging effect as a decision of a lower federal court with respect to state law issues, such as a statute's meaning. The Court's constitutional determination about the validity of a statute as construed, however, must be conclusive in any subsequent state court proceeding as a matter of federal supremacy. Since an overbreadth ruling is crucially dependent on the question of a statute's meaning-a matter of state law-the practical effect, explained below, would be that a Supreme Court determination of overbreadth in a case of this kind would have immunizing effects only for the conduct of the parties to the action. It would not have the broader immunity effect that exists when the Supreme Court renders its overbreadth judgment on review of a state court enforcement action. The disparity is appropriate because, in the latter kind of case, but not the former, the state court has failed to provide the constitutionally requisite narrowing construction on the facts of the particular case before the Court. There is, accordingly, no risk of federal judicial error in construing the statute, and the state court will have foregone an opportunity to do what it ought to have done: either invalidate the overbroad statute or furnish a constitutionally adequate narrowing construction.

283. See supra note 6 and accompanying text. 
a narrowing construction in state court, succeeds in having the declaratory judgment or injunction vacated on that basis, and then attempts to prosecute the party for conduct that occurred prior to the narrowing construction. Is the party immunized? This is, of course, another question left open by the Dombrowski dictum. ${ }^{284} \mathrm{My}$ answer once again is that the federal judgment ought to confer immunity. ${ }^{285}$ To the extent that the rationale for overbreadth doctrine lies in an aspiration to cure the chill of an overbroad statute, temporary protection would often prove inadequate.$^{286}$ It is "often only marginally better than no protection at all."287 To the extent that the prophylactic aspect of overbreadth doctrine seeks to affect the ways that states draft and construe their laws, a similar conclusion obtains. Giving immunity to the beneficiaries of a federal judgment for conduct occurring prior to the judgment's being vacated seems the minimal cost that could possibly be expected to prove effective. ${ }^{288}$ Supreme Court review occurs too infrequently to create the desired incentive.

Even the recommended "minimal" cost is not, of course, trivial, and, as I have emphasized, courts may impose the cost erroneously. It is for this reason that questions about the appropriate predicate for a lower federal court's holding a state statute overbroad so often blend with questions about the applicability of federal abstention doctrines. ${ }^{289}$ The Pullman doctrine, ${ }^{290}$ in particular, authorizes federal courts, in appropriate circumstances, to "abstain" from deciding federal constitutional questions, including the question of overbreadth, until a state court has decided state law questions that are presented by the same case. ${ }^{291}$ Exploration even of the most basic questions surrounding abstention doctrine is too large a project to pursue here. But an observation is in order. When a statute is substantially overbroad, the legislature has likely failed to take First Amendment rights sufficiently seriously; and when no narrowing construction suggests itself, a state court is unlikely to be able to truncate the statute adequately except through an indefinitely long string of prosecutions and

284. See supra note 149.

285. For a policy argument to this effect, see Note, supra note 5 , at 852 n.246.

286. See Edgar v. MITE Corp., 457 U.S. 624, 656 n.1 (1982) (Marshall, J., dissenting) (arguing that people will be "reluctant to challenge [the validity of a statute] unless they can obtain permanent immunity from penalties").

287. Id. at 658 .

288. In terms of the schematized list of possible consequences of a federal court's overbreadth holding, presented above in Section V.B., the one less costly alternative--allowing the state to proceed even against a party to the federal action once it had obtained a narrowing construction-would not necessarily deprive the state of the opportunity to vindicate its statutory policy in even a single case. If the assumption is granted that state legislatures can be influenced by the threatened consequences of a court's invalidating a statute on overbreadth grounds, see supra note 221 , it seems reasonable to assume that it would take at least one lost opportunity for a statute to be enforced for the overbreadth doctrine to achieve its desired deterrent effect. 1359.

289. See, e.g., Houston v. Hill, 482 U.S. 451, $467-71$ (1987); HART \& WECHSLER, supra note 13, at

290. See Railroad Comm'n v. Pullman Co., 312 U.S. 496 (1941).

291. For an overview of Pullman abstention doctrine and related issues, see HART \& WECHSLER, supra note 13, at 1354-83. The best critical analysis of the doctrine remains Field, Abstention in Constitutional Cases: The Scope of the Pullman Abstention Doctrine, 122 U. PA. L. REV. 1071 (1974). 
narrowing interpretations that mark off certain sorts of conduct as constitutionally privileged. ${ }^{292}$ In these circumstances, some sanction may often be necessary to create ex ante incentives for state legislatures and courts to alter their behavior in accordance with First Amendment values. The familiarly cited standard thus seems generally on the mark: "[T]he pivotal question in determining whether abstention is appropriate is whether the statute is 'fairly subject to an interpretation which will render unnecessary or substantially modify the federal constitutional question.' "2993 When the statute is clear, or there is no reasonable possibility that a limiting construction will emerge, the federal court should not abstain. ${ }^{294}$ This is not to say that the federal court should hold the statute overbroad-just that it should address the issue.

A related potency issue has to do with the direct expansion of the protective effects of a lower court's determination of overbreadth by substituting class for individual relief. Where a class is properly certified, all class members should receive the immunity that would run to an individual plaintiff under the standard endorsed above. ${ }^{295}$ The issues surrounding class relief thus meld general concerns about the appropriate standards for class actions with the peculiar features of First Amendment overbreadth doctrine. On the one hand, class action relief can be enormously costly to the states in overbreadth cases, ${ }^{296}$ and, once again, the costs occur in a situation that involves an unavoidable risk of federal judicial error. On the other hand, as Professor Laycock has argued, ${ }^{297}$ class relief may be necessary to give effective protection to federal policies. Class relief may be singularly effective in obviating chill. In any case, its threat should create a substantial incentive for state legislatures and courts to keep state law within constitutional bounds.

The resolution of these competing concerns ought to be relatively context-specific. David Shapiro is certainly persuasive that federal courts should not be "trigger-happy" about granting class certification in overbreadth cases. ${ }^{298}$ Professor Laycock is equally convincing that class relief is sometimes necessary for First Amendment rights to be protected effectively at all. ${ }^{299}$ Examples include challenges to statutes that impede organized political activity and that threaten the exercise of protected associational rights.

292. See, e.g., Board of Airport Comm'rs v. Jews for Jesus, 482 U.S. 569, 575-76 (1987).

293. Hill, 482 U.S. at 468 (quoting Harmon v. Forssenius, 380 U.S. 528, 534-35 (1965)). Even when uncertainty exists, a lower federal court can nearly always hold that a state cannot lawfully apply a statute to conduct that the court identifies as constitutionally privileged. See Shapiro, supra note 4, at 767 . This course should generally prove adequate to protect a particular litigant's personal constitutional rights, and nonparties are unlikely to be able to claim immunity under a federal judgment anyway. See supra text accompanying note 6 .

294. See Hill, 482 U.S. at 468.

295. See Shapiro, supra note 4 , at 768-79.

296. See id. at 778.

297. Laycock, Federal Interference with State Prosecutions: The Need for Prospective Relief, 1977

SUP. CT. REV. 193, 220-21; see also Shapiro, supra note 4, at 778.

298. Shapiro, supra note 4, at 769-70.

299. See Laycock, supra note 297 , at 219-22. 
A mediating solution may sometimes have much to commend it: a lower federal court might temporarily restrain the enforcement of a statute on grounds of overbreadth, but certify the question of the statute's actual construction to a state court. ${ }^{300}$ This course would raise in new form an acutely difficult question that was introduced earlier: ${ }^{301}$ whether a federal declaratory judgment or injunction that is subsequently vacated or reversed on grounds of legal error ought nonetheless to immunize conduct occurring during its pendency. My own judgment would be that it should, and perhaps especially in cases such as this, where such immunization may be necessary to encourage federal district courts to pursue the eminently sensible course of certifying a potentially difficult state law question to a state court.

A final question about the appropriate potency of a lower federal court's determination of overbreadth involves the effect that such a judgment ought to have in habeas corpus actions: once a federal court has determined that a state statute is overbroad, should it invalidate all convictions obtained under that statute that are properly subject to federal habeas corpus review? The answer, I think, is no. ${ }^{302}$ It must always be borne in mind that the federal action may be based on an erroneous understanding of state law. Moreover, even where the federal court's interpretation is correct, the costs that are imposed on the state under a prophylactic theory of overbreadth should not be made excessive in relation to expected gains. ${ }^{303}$ Within this calculus, there is no need to free state prisoners whose constitutionally unprotected conduct the state has deemed antisocial and punishable. Lesser costs should achieve the desired effects of reducing chill and creating an incentive for constitutionally sensitive action by state legislatures and courts.

\section{The RELATION OF VAgUeNESS to OVERBREADTH}

I have so far avoided discussions of First Amendment vagueness doctrine and cannot, here, deal with the subject in any detail. As a conceptual matter, however, much of the foregoing analysis applies as much to First Amendment vagueness as to overbreadth issues. Vagueness doctrine, in its most familiar form, holds that criminal prohibitions, at least, may not be enforced when they are so unclear that people of ordinary intelligence would need to guess at

300. See generally HART \& WECHSLER, supra note 13, at 580-81, 1378-83 (discussing availability and mechanics of certification); Gerwatowski, Of Comity and Common Sense: The Need for Federal Courts to Certify Unsettled Questions of State Constitutional Law, 75 MASS. L. REv. 3 (1990) (asserting desirability of certification).

301. See supra note 191.

302. Rule-of-law based challenges should, of course, be entertained to the extent that applicable procedural limits on the availability of habeas corpus permit.

303. Cf. Osborne v. Ohio, 110 S. Ct. 1691, 1702-03 \& n.15 (1990) (suggesting that requiring vacating of previous convictions under statute held overbroad would "very likely invite reconsideration or redefinition" of First Amendment overbreadth doctrine). 
whether their conduct was or was not forbidden. ${ }^{304}$ Although applicable in First Amendment cases, this minimal demand for fair notice does not stem from the First Amendment, and is not peculiar to free speech jurisprudence; the requirement of fair, individual warning stems from the due process clause. ${ }^{305}$ There is, however, a separate, additional vagueness doctrine that applies in First Amendment cases and other cases involving rights protected by strict scrutiny; ${ }^{306}$ as does overbreadth doctrine, First Amendment vagueness doctrine allows courts to declare statutes facially invalid, ${ }^{307}$ not merely unconstitutional as applied, and it may sometimes allow one party to challenge the lawfulness of a statute on the ground that it is vague and reaches "a substantial amount" of protected conduct without establishing that the statute is either "vague in all its applications" 308 or even vague as to the particular conduct charged. ${ }^{309}$ The purpose of this exception to "ordinary" or non-First Amendment vagueness doctrine, as with the parallel "ordinary" and "First Amendment" overbreadth doctrines, ${ }^{310}$ is to avoid the chilling of constitutionally protected expression, ${ }^{311}$ and to reduce the possibility that an open-ended delegation of authority may lead to "selective enforcement against unpopular causes." 312

At a minimum, the First Amendment overbreadth and vagueness doctrines have common rationales. But a stronger claim is warranted: First Amendment vagueness doctrine-as distinct from ordinary or non-First Amendment vagueness doctrine-is best conceptualized as a subpart of First Amendment overbreadth doctrine. ${ }^{313}$ The reason has to do with the appropriate scope of First

304. See, e.g., Kolender v. Lawson, 461 U.S. 352, 357 (1983); Connally v. General Const. Co., 269 U.S. 385, 391 (1926).

305. See, e.g., Papachristou v. Jacksonville, 405 U.S. 156, 162 (1972). For a skeptical appraisal of how far the goal of warning is in fact achieved, see Jeffries, supra note 204.

306. See L. TRIBE, supra note $24, \S 12-31$, at 1034.

307. See, e.g., Kolender v. Lawson, 461 U.S. 352 (1983).

308. Id.

309. In Kolender, id. at 359 n.8, a majority of the Court termed vagueness "logically related and similar" to overbreadth and, on this basis, rejected "the dissent's view" that vagueness doctrine, unlike overbreadth doctrine, will not permit a challenger to attack a statute as being unconstitutional "'as applied to conduct other than his own." It is indisputable, however, that the Court has sent mixed signals as to whether a party may challenge a statute, which clearly applies to her conduct, on the ground that it would be impermissibly vague as applied to the different conduct of someone else. Compare Gooding v. Wilson, 405 U.S. 518, 521 (1972) (suggesting affirmative answer) with Broadrick v. Oklahoma, 413 U.S. 601, 608 (1973) (suggesting negative answer). For a brisk survey of relevant cases, see M. NMMER, NIMMER ON FREEDOM OF SPEECH: A TREATISE ON THE THEORY OF THE FIRST AMENDMENT § 4.11, at 4-159 to 4-162 (Student ed. 1984).

310. See supra Sections II.A-B.

311. See, e.g., Smith v. Goguen, 415 U.S. 566, $572-73$ (1974); Grayned v. Rockford, 408 U.S. 104, $109 \&$ n.5 (1972).

312. NAACP v. Button, 371 U.S. 415,435 (1963). See, e.g., Kolender, 461 U.S. at 357-61; Grayned, 408 U.S. at 108-09.

313. As the discussion that follows will illustrate, this claim is in no way inconsistent with the truism that "not all overbroad laws are vague (e.g., 'No person may expressly advocate criminal conduct'), and not all vague laws are overbroad (e.g., "No person may engage in any speech that the state may constitutionally restrict')." G. STONE, L. SEIDMAN, C. SUNSTEN, \& M. TUSHNET, supra note 40, at 1043. 
Amendment vagueness doctrine. Imagine a statute that defines a class of publications as "obscene" and therefore as prohibitable by means of a test that satisfies all pertinent constitutional requirements concerning the definition of obscenity, but prohibits the sale only of a smaller subclass, defined to encompass those obscene publications "that would be found to be exceptionally morally repugnant by persons of ordinary sensibilities." If the subclass is not further defined, I assume that the criminal prohibition is vague (since it would be uncertain in many cases whether a magazine or film would be regarded as "exceptionally morally repugnant" by persons of ordinary sensibilities), but not overbroad (since no publication could fall within the prohibition unless it were "obscene" in the constitutional sense, and therefore constitutionally unprotected). Imagine further that someone is prosecuted under the statute for selling a film that depicts acts so outrageously repugnant that the statute could not reasonably be held vague as applied to her. Is she entitled to invoke "First Amendment vagueness" doctrine and to argue that the statute would be vague in a substantial number of its possible applications? It seems clear that she should not be, and for a simple reason: in this type of case the rationale of the doctrine does not apply. There is no substantial threat of chilling constitutionally protected speech, or of selective enforcement that is constitutionally troublesome. If this is so, however, it suggests that vagueness is especially troubling in the free speech area only insofar as a vague statute is susceptible of being so construed as to be constitutionally overbroad. ${ }^{314}$ In other words, we have reason to be sufficiently worried about vagueness to want a special First Amendment vagueness doctrine only insofar as vagueness threatens constitutionally protected speech-that is, only insofar as vague statutes are, or are too likely to be experienced as, overbroad.

Professor Tribe appears to disagree. In his view, a judicial construction that "prun[es] a statute of [all of] its overbroad sections" may nonetheless leave "the remainder impermissibly vague." ${ }^{315}$ In support of this conclusion, Tribe offers a paradigmatic problem: a judicial "limiting construction," which could apparently be made part of the boilerplate of every judicial opinion rejecting a constitutional challenge, to the effect that the statute should be understood to reach no further than the Constitution allows. ${ }^{316}$ So construed, a statute could not be "overbroad" in the literal sense, but it would remain so in a functional sense, since people who feared being prosecuted or named as defendants in a lawsuit might continue to be chilled from engaging in constitutionally protected conduct. In response to this problem, Tribe concludes that "[a]n overbroad statute can be given a saving construction only if it is possible to define a precise category of conduct privileged by the First Amendment which can be

314. See Shaman, The First Amendment Rule Against Overbreadth, 52 TEMPLE L.Q. 259, 263 (1979).

315. L. TRIBE, supra note $24, \S 12-29$, at 1030.

316. See id. at 1031. 
clearly stated to fall outside the reach of the restructured statute." ${ }^{317}$ In the first edition of his treatise, he gave bite to this assertion by claiming that the Supreme Court's canonical formulations of the "clear and present danger" and "fighting words" tests, if adopted by state courts as aspects of limiting constructions of state statutes, would be too vague to pass constitutional muster. ${ }^{318}$

Tribe's specific claims about the "clear and present danger" and "fighting words" tests appear to be mistaken even when evaluated in light of the cases that he cited for support. ${ }^{319}$ The Supreme Court has not held, or even implied,

317. Id. at 1031 n.9.

318. See L. TRIBE, AMERICAN CONSTTtuTIONAL LAW $\S 12-26,715-16$ \& n.9 (1st ed. 1978). Tribe wrote:

An example of [a constitutional test that is too vague to pass muster as a saving construction of an overbroad statute] is ... [the] definition of 'fighting' words [furnished by Chaplinsky v. New Hampshire, 315 U.S. 568, 573 (1942)]: those having " 'a direct tendency to cause acts of violence by the persons to whom, individually, the remark is addressed'." The Chaplinsky standard is obviously not precise and focused enough to give advance waming of the exact reach of a statute punishing offensive speech, since decisions under the standard turn on facts particular to the speaker, the audience, and their interaction. Because of the test's indefiniteness from any vantage point other than hindsight, the Supreme Court in Gooding v. Wilson [405 U.S. 518 (1972)] and in a series of cases based on Gooding, has declined to reconstruct statutes punishing offensive speech by judicially limiting the reach of the statutes to "fighting words." To construe a statute by reference to such a fact-oriented standard is to inject an excessive element of vagueness into the law because the standard itself takes shape only as courts proceed on a retrospective, case-bycase basis to determine when offensive speech has become unprotected as an instance of "fighting words."

Id. (footnotes omitted). A footnote to the quoted text asserted that "[t]he Supreme Court's application of the 'clear and present danger' standard in cases involving government regulation of subversive advocacy and association .... is another illustration of the use of the case-by-case approach to determine ... the validity of a claim of First Amendment privilege" and, because of the failure of such a standard to give clear, advance warning of what conduct is and is not prohibited, that a statute written to prohibit speech in terms of that standard would be too vague to survive a facial challenge. $I d$. at $715 \mathrm{n} .9$.

319. The cases cited as providing direct support all involved Supreme Court reversals or vacations of convictions under statutes or ordinances prohibiting the use of offensive or opprobrious language: Lewis v. City of New Orleans, 415 U.S. 130 (1974) (Lewis II); Brown v. Oklahoma, 408 U.S. 914 (1972); Lewis v. City of New Orleans, 408 U.S. 913 (1972) (Lewis I); Rosenfeld v. New Jersey, 408 U.S. 901 (1972); and Gooding v. Wilson, 405 U.S. 518 (1972). In none of the cases, however, had the state court specifically interpreted the relevant statute or ordinance as being limited in its reach to words within the prohibitable category as defined by Chaplinsky v. New Hampshire, 315 U.S. 568, 573 (1942)-i.e., as limited to words that "have a direct tendency to cause acts of violence by the persons to whom, individually, the remark is addressed." Id. at 573. In Gooding, the case on which Professor Tribe placed heaviest weight, the Court found the Chaplinsky doctrine inapplicable, since the decisions of the Georgia courts had not limited the statute's application to words that came within the Chaplinsky standard. 405 U.S. at 524. As a result, the Court found that the statute, as construed, "does not define the standard of responsibility with requisite narrow specificity." Id. at 527. As Professor Redish has argued, "[i]f . . . the Georgia courts had read the Chaplinsky standard into the statute, the decision might well have been different." Redish, supra note 2, at 1054. The state courts had similarly failed to read the Chaplinsky standard into the relevant statutes and ordinances in Rosenfeld, Brown, and Lewis I. In Lewis II, the Louisiana state court, on remand from the Supreme Court's decision in Lewis $l$, did assert that the relevant city ordinance "is narrowed to "fighting words' uttered to specific persons at a specific time." 415 U.S. at 132 (quoting 263 La. 809, 826, 269 So. 2d 450, 456 (1972)). According to the Supreme Court, however, the Louisiana Supreme Court, despite its reference to "fighting words," "contemplated a broader reach of the ordinance" than is permitted under the "constitutional definition of 'fighting words' announced in Chaplinsky ... and reaffirmed in Gooding ...., namely, "those [words] which by their very utterance inflict injury or tend to incite an immediate breach of the peace." Id. In other words, despite the Louisiana Supreme Court's reference to "fighting words," the substance of the Chaplinsky definition had not been read into the ordinance, and the Court gave no suggestion that, if it had, the ordinance as so construed would not have been upheld. Although the first 
that a state statute construed to incorporate the specific language used by the Court in defining these prohibitable categories of speech would be unconstitutionally vague. ${ }^{320}$ Nor do specific claims about particular tests appear in the second edition of Professor Tribe's treatise. The more general claim remains, however, as a seemingly plausible response to an undeniable doctrinal puzzle. Yet the general claim, too, appears in a new light when the more specific assertions are seen to fail.

The better analysis, I think, is that statutes "narrowed" merely by an assertion that they reach only as far as the Constitution permits, without citation of more specific limitations, remain functionally overbroad. In light of the prophylactic character of First Amendment overbreadth doctrine, and its characteristic concern with practical effects, it is wholly consistent with the doctrine's logic for statutes that are "functionally overbroad" to be invalidated, especially when their "limiting constructions" fail to incorporate specific, available tests that are sufficiently precise to function as "less drastic means" 321 of achieving permissible state ends. As the reference to "less restrictive means" suggests, determinations of functional overbreadth should and could be made within a formula very much like that used for determining overbreadth in the more general run of First Amendment cases. But the concept of "functional overbreadth," it should be emphasized, should play only the limited role of dealing with the troublesome sort of case that bothers Professor Tribe. Ordinarily, a state statute that precisely tracks judicially specified constitutional limits should be found neither overbroad nor vague.

\section{CONCLUSION}

The truism that First Amendment overbreadth is strong medicine should not obscure analysis of the actual effects of an overbreadth ruling. First Amendment overbreadth doctrine consists of two components. One, which reflects the ideal of the rule of law, is necessarily potent but narrow in scope. The other component, which sweeps much more broadly in practice, is prophylactic. Its shape not mandated by the Constitution, prophylactic overbreadth is a judge-made doctrine aimed at eliminating the chilling effect of overbroad statutes and, even more importantly, at inducing state legislatures to craft statutes narrowly and state courts to furnish narrowing constructions. The contours of the prophylactic component of overbreadth doctrine, and the strength of the "medicinal" effects of prophylactic overbreadth holdings, are matters for judicial deliberation and ultimately for judicial choice.

edition of 'Tribe's treatise also stated that the Supreme Court's recent formulations of the "clear and present danger" standard would be too vague to save a statute from facial invalidation, L. TRIBE, supra note 318 , $\S 12-26$, at $715 \&$ n.9, Tribe cited no Supreme Court cases in support of his claim.

320. See Redish, supra note 2, at 1053-56.

321. Shelton v. Tucker, 364 U.S. 479,488 (1960). 
With regard to the contours of the doctrine, various categories of overbroad statutes can usefully be distinguished. In general, courts should be more willing to find impermissibly substantial overbreadth, and to administer the medicine of a declaration to that effect, when the underlying statute is likely to reflect or to provide a cover for content-based hostility to constitutionally protected expressive activity. The strength of the overbreadth medicine should also vary with context. The doctrine should aim to reduce the chill of currently overbroad statutes and to create incentives for legislatures to draft their regulations narrowly when First Amendment interests are substantially implicated, but not to impose costs on the state that are needlessly or disproportionately large. In general, Supreme Court holdings of overbreadth that are rendered in reviewing state court enforcement actions should confer immunity on all conduct occurring after the judgment is entered and before a constitutionally adequate narrowing construction is obtained. Although the jail doors generally need not swing open for all those previously convicted under an overbroad statute, and final judgments in civil cases need not be upset, some significant cost must be imposed to create the needed incentives for state legislatures and state courts. In injunctive and declaratory judgment actions in the lower federal courts, a different rule should obtain. The prevailing party should be immunized for all conduct occurring during the pendency of the federal judgment of overbreadth. Nonparties, on the other hand, should not be able to claim immunity as a necessary consequence of the federal judgment, and courts should adopt a cautious attitude toward class certification.

Although these recommendations sound in specific terms, I have aspired less to "solve" the overbreadth problem than to clarify it-to show what is constitutionally mandated and what is appropriately subject to judicial choice, and to illuminate some of the considerations that sound decisionmaking within the discretionary range ought to take into account. Too often, discussions of First Amendment overbreadth have occurred on a plane that obscures the doctrine's connections with the intricacies of practice and procedure in a federal system that includes coordinate systems of state and federal courts. When overbreadth doctrine is located in this matrix, there is no longer one problem or puzzle, but a host of smaller ones. The animating conviction of this Article is that First Amendment overbreadth doctrine, when properly understood and circumscribed, has a useful role to play in making our federal structure work. But the doctrine's occurs in varied contexts, and it should be structured accordingly. 